\title{
Biopolymers from lactic acid bacteria. Novel applications in foods and beverages
}

\author{
María I. Torino*, Graciela Font de Valdez and Fernanda Mozzi * \\ Technology Department, Centro de Referencia para Lactobacilos - Consejo Nacional de Investigaciones Científicas y \\ Técnicas, San Miguel de Tucumán, Argentina
}

\section{OPEN ACCESS}

Edited by:

Julia Ines Fariña,

Consejo Nacional de Investigaciones

Cientificas y Técnicas, Argentina

Reviewed by:

Analia Graciela Abraham,

Centro de Investigacion y Desarrollo en Criotecnologia de Alimentos,

Argentina

Clarissa Schwab,

ETH Zurich, Switzerland Michael Gänzle,

University of Alberta, Canada

*Correspondence:

María I. Torino and

Fernanda Mozzi,

Technology Department, Centro de Referencia para Lactobacilos Consejo Nacional de Investigaciones Cientificas y Técnicas,

Chacabuco 145, San Miguel

de Tucumán 4000, Argentina mitorino@cerela.org.ar; fmozzi@cerela.org.ar

Specialty section:

This article was submitted to Microbiotechnology, Ecotoxicology and Bioremediation,

a section of the journal

Frontiers in Microbiology

Received: 30 March 2015

Accepted: 29 July 2015

Published: 11 September 2015

Citation:

Torino Ml, Font de Valdez G and Mozzi F (2015) Biopolymers from lactic acid bacteria. Novel applications

in foods and beverages.

Front. Microbiol. 6:834.

doi: 10.3389/fmicb.2015.00834
Lactic acid bacteria $(\angle A B)$ are microorganisms widely used in the fermented food industry worldwide. Certain LAB are able to produce exopolysaccharides (EPS) either attached to the cell wall (capsular EPS) or released to the extracellular environment (EPS). According to their composition, LAB may synthesize heteropolysaccharides or homopolysaccharides. A wide diversity of EPS are produced by LAB concerning their monomer composition, molecular mass, and structure. Although EPS-producing $L A B$ strains have been traditionally applied in the manufacture of dairy products such as fermented milks and yogurts, their use in the elaboration of low-fat cheeses, diverse type of sourdough breads, and certain beverages are some of the novel applications of these polymers. This work aims to collect the most relevant issues of the former reviews concerning the monomer composition, structure, and yields and biosynthetic enzymes of EPS from LAB; to describe the recently characterized EPS and to present the application of both EPS-producing strains and their polymers in the fermented (specifically beverages and cereal-based) food industry.

Keywords: exopolysaccharides, homopolysaccharides, heteropolysaccharides, lactic acid bacteria, fermented foods, fermented beverages, sourdough

\section{Introduction}

Since ancient times lactic acid bacteria (LAB) have been empirically exploited as starter cultures to improve the preservation, nutritional value, and sensorial characteristics of a variety of fermented foods and products derived from animal and vegetable origins (Wood and Holzapfel, 1995; Wood, 1997; Leroy and De Vuyst, 2004). LAB have been rationally applied as lactic starter cultures in the fermented food industry since the 1930s-1940s. In addition, certain LAB strains have been used as probiotics because of their health-promoting effects in the host (Foligné et al., 2013; Martín et al., 2013; Borges et al., 2014). Due to their long history of safe use in human consumption, some LAB strains have the Qualified Presumption of Safety (QPS) or Generally Recognized As Safe (GRAS) status (EFSA, 2010).

In addition to their main feature, which is lactic acid production from the carbon source present in the matrix where they grow, several LAB strains form other compounds such as vitamins, bioactive peptides, antibacterial compounds, aroma compounds, low-calorie sugars, exopolysaccharides (EPS), etc. All these traits confer desirable attributes to specific fermented foods and products (Hugenholtz, 2008; LeBlanc et al., 2013; Ortiz et al., 2013). In this respect, efforts have been made to use LAB as microbial cell factories for the production of industrially interesting metabolites either to be used as purified compounds or to be produced in situ in fermented foods (Hugenholtz, 2008; Gaspar et al., 2013; Boguta et al., 2014). 
In this work, we aimed to collect the most relevant issues of former reviews on EPS from LAB such as their monomer composition, structure, yields and biosynthetic enzymes; to describe the recently characterized EPS and to present the application of both EPS-producing strains and their polymers in the fermented (specifically beverages and cereal-based) food industry.

Several reviews on EPS produced by LAB have been published dealing mainly with the physiology, biosynthesis, chemical and structural characteristics of the EPS molecules. To our criteria, the most relevant and detailed works covering these topics through the last decade include those from Ruas-Madiedo and de los Reyes-Gavilán (2005), Badel et al. (2011), Patel et al. (2012), Leemhuis et al. (2013b). Regarding the health-promoting benefits of these polymers two reviews on their immunomodulatory activity and prebiotic effects were recently addressed by Ryan et al. (2015) and Salazar et al. (2015).

\section{EPS Classification, Biosynthesis, and Yields}

As the majority of bacteria, LAB can synthesize cell-wall structural polysaccharides such as peptidoglycan and lipoteichoic acids, and exocellular polymers. The latter include both capsular polysaccharides (CPS), covalently bound to the cell surface, and EPS, which may form a loosely bound layer that can also be secreted into the environment (Chapot-Chartier et al., 2011).

Exopolysaccharides from LAB are highly diverse and can be classified following different criteria. The most classical one is based on their monomer composition, which allows classifying them into two major groups: homopolysaccharides (HoPS) and heteropolysaccharides (HePS).

\section{Homopolysaccharides}

The most notorious advance in the research on EPS from $\mathrm{LAB}$ in the last decade has been related to HoPS. Indeed, the isolation of HoPS-producing strains (mainly belonging to the Weissella genera), the molecular and structural characterization of these EPS, studies on their biosynthetic enzymes, and the HoPS application in food have been described (Galle and Arendt, 2014; Lynch et al., 2014; Tingirikari et al., 2014; Wolter et al., 2014a,b).

Homopolysaccharides contain one neutral monosaccharide type either glucose (glucans), fructose (fructans), or galactose (polygalactan) (Monsan et al., 2001; Mozzi et al., 2006; RuasMadiedo et al., 2008). Among LAB, a sub-classification has been established depending on the linkage type and the position of the carbon involved in the bond. Thus, glucans can be sub-classified into (i) $\alpha$-glucans [dextran: $\alpha$-D-Glc $(1,4)$; mutan: $\alpha$-D-Glc $(1,3)$; alternan: $(\alpha-\mathrm{D}-\mathrm{Glc}(1,6) / \alpha-\mathrm{D}-\mathrm{Glc}(1,3)$; and reuteran: $\alpha$-D-Glc $(1,4) / \alpha-D-G l c(1,6)$ with $\alpha$-D-Glc $(1,4) / \alpha-D$ $\operatorname{Glc}(1,6)$ branching points], and (ii) $\beta$-glucans $[\beta$-D-Glc $(1,3)$ with side chain linked $(1,2)]$. Fructans can be classified into (i) levan-type: $\beta$-D-Fru(2,6), and (ii) inulin-type: $\beta$-D-Fru $(2,1)$, being both $\beta$-fructans. Finally, polygalactans, which contain a pentameric repeating unit of galactose; these polymers being more rare and were only described for the strain Lactococcus. lactis subsp. lactis H414 (van Kranenburg et al., 1999) and two strains of Lactobacillus delbrueckii subsp. bulgaricus (CRL 406 and 142; Mozzi et al., 2006). Recently, a polygalactancontaining CPS from the strain Lactobacillus plantarum 70810 was analyzed by different techniques (GC-MS, gas chromatography-mass spectrometry; FTIR, fourier transform infrared spectroscopy; and NMR, nuclear magnetic resonance) resulting in a low molecular weight $(\mathrm{MW})$ polymer of $1.7 \mathrm{kDa}$ with a repeating unit of $\alpha$-D-(1,6)-linked galactcosyl, $\beta$-D- $(1,4)$ linked galactcosyl, $\beta$-D-(1;2,3)-linked galactcosyl residues and a tail end of $\beta$-D (1,)-linked galactcosyl residue (Wang et al., 2014).

Traditional fermented foods can be a rich source of HoPSproducing LAB as well as of different polymers. Recently, several dextran-producing LAB strains from sourdoughs and indigenous Asian foods were isolated (Table 1).

In addition Park et al. (2013) have isolated dextran-like polymer-producing strains belonging to the genera Leuconostoc and Weissella from kimchi. The MW of these HoPS being about $1.1 \times 10^{6} \mathrm{Da}$; FTIR analysis showed that these polymers had a similar structure to that of commercial dextran from Leuc. mesenteroides B-512F. Leuconostoc strains produce putative alternan polymers being those $\alpha-(1,2)$ branched polymers particularly high (Passerini et al., 2015). Interestingly, the ${ }^{1} \mathrm{H}$ NMR spectra of the EPS produced by L. curvatus $69 \mathrm{~B} 2$ and Leuc. lactis 95A showed that the HoPS formed was constituted by a single repeating glucopyranosyl unit linked by an $\alpha-(1,6)$ glycosidic bond in a dextran-type carbohydrate (Palomba et al., 2012).

Patel et al. (2012) showed that some strains of L. fermentum, L. sakei, and $L$. hilgardii produced $\alpha-(1,6)$ glucans ramified by glucose residues at position 3 , and at lesser extent at positions 2 and 4 (dextran). The degree of branching involving $\alpha-1,2$, $\alpha-1,3$ and $\alpha-1,4$ linkages varying according to the origin of the biosynthetic enzymes.

Some species such $L$. reuteri, a predominant HoPS producer, is also able to generate different types of EPS including dextran (Rühmkorf et al., 2013), levan, inulin-type fructan, mutan, and reuteran with a broad MW range. Also, the single strain L. reuteri 121 synthesizes several HoPS when grown under the same culture conditions (van Geel-Schutten et al., 1999; van Leeuwen et al., 2009; Pijning et al., 2012).

Respect to HoPS biosynthesis, these polymers are mainly synthesized extracellularly from an existing sucrose molecule, which acts as donor of the corresponding monosaccharide by action of a single type of extracellular enzyme belonging to the glycosyl hydrolase (GH) family. Thus, $\alpha$-glucans and $\beta$-fructans are formed by glucansucrases (GS; GH family 70) and fructansucrases (FS; GH family 68), respectively (http://www. cazy.org; Cantarel et al., 2009). Generally, these enzymes catalyze the polymerization of the HoPS out of sucrose as donor of the corresponding monosaccharide and transfer the molecule to the reducing end of the glucan or fructan, respectively (Korakli and Vogel, 2006; van Hijum et al., 2006; Chapot-Chartier et al., 2011; Leemhuis et al., 2012). Both enzymes are typical transglycosylases or glycansucrases displaying a dual mode of action as they can cleave the glycosidic bond in sucrose (hydrolysis reaction) and 
TABLE 1 | Dextran-producing LAB strains and properties of their polymers.

\begin{tabular}{|c|c|c|c|c|c|}
\hline Microorganisms & Source & Dextran characteristics ${ }^{\&}$ & $\begin{array}{l}\text { Structural } \\
\text { studies* }\end{array}$ & Molecular studies & Reference \\
\hline $\begin{array}{l}\text { Leuconostoc } \\
\text { mesenteroides } \\
\text { NRRL B-1149 }\end{array}$ & Sugar-cane juice & $\begin{array}{l}\text { Insoluble } \\
\text { (medium used: sucrose, } 10.0 \% \text {; } \\
\text { maltose, } 5.0 \% \text {; } 20 \mathrm{mM} \text { sodium } \\
\text { acetate buffer ( } \mathrm{pH}=5.4 \text { ) containing } \\
0.1 \% \text { sodium azide and purified } \\
\text { dextransucrase }(0.2 \mathrm{mg} / \mathrm{mL} \\
13 \mathrm{U} / \mathrm{mg} \text { ) } \\
\text { Fibrous structure }\end{array}$ & $\begin{array}{l}\text { FTIR, }{ }^{1} \mathrm{H} \text { NMR, }{ }^{13} \mathrm{C} \\
\text { NMR spectroscopy } \\
\text { and SEM technique }\end{array}$ & $\begin{array}{l}\text { Purification and } \\
\text { characterization of } \\
\text { dextransucrase } \\
\text { (enzyme activity in } \\
\text { SDS-PAGE) }\end{array}$ & Shukla et al., 2010, 2011 \\
\hline $\begin{array}{l}\text { Pediococcus } \\
\text { pentosaceous } \\
\text { CRAG } 3\end{array}$ & $\begin{array}{l}\text { Fermented } \\
\text { cucumber }\end{array}$ & $\begin{array}{l}\text { MM } 2.9 \times 10^{5} \\
\text { Porous structure }\end{array}$ & FTIR, NMR, SEM & $\begin{array}{l}\text { Purification and } \\
\text { characterization of } \\
\text { dextransucrase } \\
\text { (SDS-PAGE) }\end{array}$ & $\begin{array}{l}\text { Shukla and Goyal, 2013, } \\
2014\end{array}$ \\
\hline P. acidilactici M76 & $\begin{array}{l}\text { Korean fermented } \\
\text { rice wine (makgeolli) }\end{array}$ & MM $6.7 \times 10^{4}$ & SEC, FTIR & & Song et al., 2013 \\
\hline $\begin{array}{l}\text { Lactobacillus } \\
\text { hilgardii TMW } \\
1.828\end{array}$ & Water kefir & & & $\begin{array}{l}\text { Purification and } \\
\text { sequence analysis of } \\
\text { glucansucrase (GS). } \\
\text { Characterization of GS } \\
\text { activity in SDS-PAGE. } \\
\text { Identification and } \\
\text { sequence of } \\
\text { glucansucrase gene } \\
\text { [FN662554] }\end{array}$ & Waldherr et al., 2010 \\
\hline $\begin{array}{l}\text { L. acidophilus } \\
\text { ST76480.01 }\end{array}$ & $\begin{array}{l}\text { Fermented } \\
\text { vegetables }\end{array}$ & $\begin{array}{l}\text { Insoluble } \\
\text { (medium used \%: sucrose, 15.0; } \\
\text { bacto-peptone, 0.5; yeast extract, } \\
0.5 ; \mathrm{K}_{2} \mathrm{HPO}_{4}, 1.5 ; \mathrm{MnCl}_{2} . \mathrm{H}_{2} \mathrm{O} \\
0.001 ; \mathrm{NaCl}, 0.001 ; \mathrm{CaCl}_{2}, 0.005 \\
\text { and } \mathrm{pH} 7.0 \text { ) }\end{array}$ & $\begin{array}{l}\text { Rheology, }{ }^{13} \mathrm{C}-\mathrm{NMR} \\
\text { spectroscopy. }\end{array}$ & $\begin{array}{l}\text { Characterization of } \\
\text { dextransucrase activity } \\
\text { (SDS-PAGE) }\end{array}$ & Abedin et al., 2013 \\
\hline L. plantarum DM5 & $\begin{array}{l}\text { Indian traditional } \\
\text { fermented } \\
\text { beverage (Marcha) }\end{array}$ & $\begin{array}{l}\text { MM } 1.1 \times 10^{6} \\
\text { Smooth porous structure }\end{array}$ & $\begin{array}{l}\text { SEC, FTIR, NMR, } \\
\text { SEM, rheology }\end{array}$ & $\begin{array}{l}\text { Purification and } \\
\text { characterization of GS } \\
\text { (SDS-PAGE) }\end{array}$ & Das and Goyal, 2014 \\
\hline $\begin{array}{l}\text { Weissella confusa } \\
\text { MBF8-1 }\end{array}$ & $\begin{array}{l}\text { Indonesian } \\
\text { fermented soybean } \\
\text { foods (Pamulang, } \\
\text { Tangerang) }\end{array}$ & & & $\begin{array}{l}\text { Two gtf genes: gtf8-1A } \\
\text { [FJ436354] and } \\
\text { gtf8-1B [ FJ460018] }\end{array}$ & Malik et al., 2009 \\
\hline Weisella. sp. TN610 & Pear & & NMR & $\begin{array}{l}\text { Characterization of } \\
\text { dextransucrase activity } \\
\text { (SDS-PAGE). } \\
\text { Sequence of gtf gene } \\
\text { [HE818409] }\end{array}$ & Bejar et al., 2013 \\
\hline W. cibaria MG1 & Sourdough & $\begin{array}{l}3 \times 10^{9}, 5 \times 10^{6}-4 \times 10^{7} \\
\text { GOS is formed in addition to } \\
\text { dextran when maltose is present }\end{array}$ & $\begin{array}{l}\text { FFF, SEC, } \\
\text { HPAEC-PAD }\end{array}$ & $\begin{array}{l}\text { Genome sequence } \\
\text { including the gtf gene } \\
\text { (JWHU00000000) }\end{array}$ & $\begin{array}{l}\text { Galle et al., 2010, 2012a,b; } \\
\text { Zannini et al., 2013; } \\
\text { Lynch et al., 2014; } \\
\text { Wolter et al., 2014a,b }\end{array}$ \\
\hline W. cibaria JAG8 & Apple peel & Porous structure & $\begin{array}{l}\text { DLS spectroscopy } \\
\text { (monodisperse), } \\
\text { SEM }\end{array}$ & $\begin{array}{l}\text { Purification of } \\
\text { dextransucrase; in vitro } \\
\text { synthesis of dextran }\end{array}$ & Rao and Goyal, 2013 \\
\hline
\end{tabular}

Information published by Ruas-Madiedo and de los Reyes-Gavilán (2005) and Badel et al. (2011) was omitted in this Table to avoid overlapping.

\&MM, molecular mass expressed in Daltons; GOS, gluco-oligosaccharides.

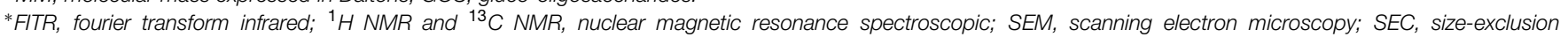

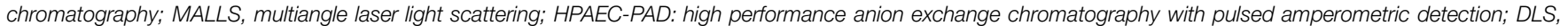
dynamic light scattering.

with the energy released they can transfer the glucosyl or fructosyl moiety (transferase reaction) to the growing reducing end of the polymer (Chapot-Chartier et al., 2011).

Glucansucrases can synthesize a variety of $\alpha$-glucans with different physicochemical characteristics such as solubility, viscosity, and other properties by altering the type of glycosidic linkage, degree of branching, length, mass, and conformation of the polymers. So far, $\alpha$-glucan formation by GS has been reported for the genera Leuconostoc, Lactobacillus, Streptococcus, Pediococcus, and Weissella. Depending on the reaction catalyzed and the specificity, GS are classified by the Nomenclature Committee of the International Union of Biochemistry and 
Molecular Biology (NC-IUBMB) in four groups: dextransucrase (EC 2.4.1.5), mutansucrase (EC 2.4.1.5), alternansucrase (EC 2.4.1.140), and reuteransucrase (EC 2.4.1.5), which catalyze $\alpha-(1,6), \alpha-(1,3), \alpha-(1,3$ and 1,6$)$, and $\alpha-(1,4$ and 1,6$)$ glycosidic linkages, respectively (Leemhuis et al., 2013b).

The in vitro synthesis of glucooligosaccharides (GOS) and fructooligosaccharides (FOS) by using selected GS and FS and electron acceptors reaction (i.e., maltose, raffinose) was reported in Lactobacillus (Tieking et al., 2005a; Ozimek et al., 2006; Katina et al., 2009; Galle et al., 2010, 2012b; Shukla and Goyal, 2014), Leuconostoc (Leemhuis et al., 2013a), and Weissella (Malang et al., 2015). This approach constitutes one of the most interesting perspectives to design short tailor-made HoPS with prebiotic activity.

Glucansucrases expression is involved in the constitutive production of HoPS as reported in the strains L. reuteri 121, 180 and $L$. parabuchneri 33 . On the contrary, the GS expression by Leuc. mesenteroides is induced by sucrose (Kralj et al., 2004), these enzymes are high MW extracellular proteins exclusively encoded by GS (gtf) genes. Variations in EPS structures, even belonging to the same group (i.e., dextran, mutan, etc.) are due to different enzymes intervention. For example, the product of the gene $\mathrm{gtf} \mathrm{Kg} 3$ from L. fermentum $\mathrm{Kg} 3$ is responsible for the synthesis of a dextran which is $89 \%$ linked by $\alpha-(1,6)$ linkages, while $g t f 180$ (from $L$. reuteri 180) encoded for a protein involved in the synthesis of a dextran with $51 \%$ of $\alpha-(1,6)$ glucosidic bonds. In addition, biosynthesis of glucans by a wine strain of Lactobacillus sp. leads to a linear dextran whereas $L$. reuteri 180 synthesizes a branched EPS (Uzochukwu et al., 2001; van Leeuwen et al., 2009). Branching is catalyzed by GS involved in the HoPS backbone synthesis; the degree of branching depending on the enzyme conformation. Some experiments accomplished on GS from the strain L. reuteri 121 showed that mutations of the gene encoding for this enzyme increased $\alpha-(1,6)$ and decreased $\alpha-(1,4)$ linkages.

The production of $\beta$-glucan has mainly been described in $\mathrm{LAB}$ isolated from alcoholic fermented beverages and its synthesis occurs intracellularly by a membrane-associated glucosyltransferase (GTF). Although its mechanism of action is not fully yet understood, it does not need sucrose as substrate (Werning et al., 2006). LAB strains belonging to the genera Pediococcus, Lactobacillus, and Oenococcus isolated from cider and wine are able to produce a 2 -substituted $(1,3)-\beta$-Dglucan (Llaubères et al., 1990; Dueñas-Chasco et al., 1997, 1998; Ibarburu et al., 2007; Dols-Lafargue et al., 2008) by a single transmembrane GTF that polymerizes glucosyl residues from UDP-glucose (Werning et al., 2006, 2008; Velasco et al., 2007; Garai-Ibabe et al., 2010). Considering the requirement of sugar nucleotide intermediates as precursors, the synthesis of $\beta$-glucans resembles HePS's synthesis and it is linked to the growth and the central carbon metabolism of the producer organism. Also, GTF are part of the enzyme machinery responsible for HePS formation (De Vuyst and Degeest, 1999). The (1,3)$\beta$-D-glucans are attractive for the pharmaceutical and functional food industries because of their beneficial effects on human and animal health (Zekovic et al., 2005). The 2-substituted $(1,3)-\beta$-D-glucan producers $P$. parvulus 2.6 and L. paracasei
NFBC 338 have been tested for the production of oat-based products, yogurt and various beverages increasing significantly their techno-functional properties (Mårtensson et al., 2002; Kearney et al., 2011). Moreover, the synthesis of the $2.6 \beta$-glucan confers higher survival to the producing-strain during the gastrointestinal passage or technological process (Stack et al., 2010).

The enzyme FS or fructosyltransferase (FS, EC 2.4.1.10) cleaves the glycosidic bond of the fructosyl-donor molecule (substrate, i.e., sucrose, raffinose, stachyose, verbascose) and uses the released energy to couple a fructose moiety to a growing fructan chain but also to sucrose or to another acceptor such as raffinose (Meng and Fütterer, 2003, 2008; van Hijum et al., 2006; Teixeira et al., 2012). As mentioned earlier, two fructan types are known, levan [with $\beta-2,6$ glycosidic bonds, produced by levansucrases (Lev, E.C. 2.4.1.10; van Hijum et al., 2004)] and inulin (with $\beta-2,1$ bonds) synthesized by inulosucrase (Inu, E.C. 2.4.1.9; van Hijum et al., 2003, 2006). Fructan production has been reported for $W$. confusa strains isolated from Malaysian soy, Malaysian coconut milk beverage (Malik et al., 2009), wheat sourdough (Tieking et al., 2003), fermented cassava (Malang et al., 2015), and for L. reuteri Lb121 (van Geel-Schutten et al., 1999) and a $L$. pontis strain (Tieking et al., 2003). Inulin biosynthesis is rare in $\mathrm{LAB}$ and only individual strains of Lactobacillus and Leuconostoc as well as a few streptococci were reported to produce inulin or to possess inulosucrase-encoding genes (van Hijum et al., 2002; Olivares-Illana et al., 2003; Schwab et al., 2007; Anwar et al., 2008, 2010). Recently, Malang et al. (2015) reported the first structural characterization of a fructantype polymer produced by a Weissella strain as well as the first Weissella strain to produce inulin in addition to oligosaccharides. By means of NMR, the soluble EPS formed by nine strains were identified as low $\alpha-1,3$-branched dextran, levan and inulin-type polymers. Besides, six isolates synthesized a highly ropy polymer together with CPS formation composed of glucose, O-acetyl groups and two unidentified monomers when using glucose as carbon source.

The fact that GTF cannot use sucrose as an acceptor but GS can, and that FS can also use raffinose, stachyose, and verbascose as substrates, are clear differences among these enzymes. Indeed, the reactions formed by FS and GS are similar with respect to the use of sucrose as a substrate (Galle and Arendt, 2014), but the proteins involved do not share a high amino acid sequence similarity and differ strongly in protein structures (Vasileva et al., 2009; Leemhuis et al., 2013b).

Due to the interest in the food industry, the number of isolations of GS-producing LAB has been rapidly increasing. The strains are typically identified on solid or liquid media supplemented with sucrose by the appearance of slimy/ropy colonies or viscous solutions. Gene knock-out studies have demonstrated that the slimy colony morphology is caused by GS activity in wild-type strains (Fujiwara et al., 2000; Waldherr et al., 2010). However, also $\beta$-fructan-producing strains form slimy colonies in the presence of sucrose. Replacing sucrose by the tri-saccharide raffinose used by FS but not by GS enzymes, allows easy identification of $\beta$-fructan-producing strains. By this means, many $\alpha$-glucan-(and $\beta$-fructan-)-forming strains have 
been identified in fermenting cabbage, fruits, and vegetables, sourdoughs, beverages, dairy, cereals, dental plaque, intestines, environmental spills of sugar plants, and in fish gastrointestinal tract (van Geel-Schutten et al., 1998; Tieking et al., 2005b; Van der Meulen et al., 2007; Kang et al., 2009; Malik et al., 2009; Bounaix et al., 2010a,b; Shukla and Goyal, 2011; Aman et al., 2012; Hongpattarakere et al., 2012). Nevertheless, the number of well-characterized GS remains behind with respect to available $g t f$ sequences as only three-dimensional structures of GS complexes (from Leuc. mesenteroides NRRL B-1299, Streptococcus mutans and L. reuteri 180) are available (VujičićŽagar et al., 2010; Ito et al., 2011; Brison et al., 2012). Expanding the structural knowledge to a wider range of GS and FS, either alone or complexed with different molecules (substrates or products) may pave the way for the rational application of HoPS. Specific information on the structurefunction relationships in GS- and FS-producing HoPS, and on their structures, reactions, and GS mechanisms has been reported by van Hijum et al. (2006) and Leemhuis et al. (2013a), respectively. The GS from strains $L$. reuteri 121 and TMW 1.106, L. curvatus TMW 1.624, L. animalis TMW 1.971, and L. hilgardii TMW 1.828 were biochemically characterized (Kralj et al., 2004; Waldherr et al., 2010; Rühmkorf et al., 2013).

The yields of HoPS produced by LAB are low as compared with other bacterial EPS (i.e., xanthan from Xanthomonas campestris) already used in the food industry. It has been reported that EPS formation by Weisella sp. and L. sanfranciscenis strains reached levels up to 16 and $5 \mathrm{~g}$ EPS/ $\mathrm{kg}$ dough, respectively, thus showing their potential to replace hydrocolloids (Galle and Arendt, 2014). Also, HoPS production values up to $10 \mathrm{~g} / \mathrm{L}$ by the strain $L$. reuteri Lb121, which simultaneously synthesizes $\alpha$-glucan and $\beta$-fructan has been reported (van Geel-Schutten et al., 1999). The MW of HoPS varies according to the producingstrain (Ruas-Madiedo et al., 2009a,b). The average MW of soluble dextran is in a range between 6.2 and $7.1 \times 10^{6} \mathrm{Da}$, bacterial inulins' MW range between 1 and $9 \times 10^{7} \mathrm{~g} / \mathrm{mol}$ (Shiroza and Kuramitsu, 1988; van Hijum et al., 2002), while the MW of levans are within the range of $10^{5}-2 \times 10^{6} \mathrm{~g} / \mathrm{mol}$ for lactobacilli and Leuconostoc sp. strains and $10^{8} \mathrm{~g} / \mathrm{mol}$ for S. salivarius (Tieking et al., 2003). Of note, the MW of Weissella levans $\left(1.4 \times 10^{5}-\right.$ $\left.1.7 \times 10^{7} \mathrm{~g} / \mathrm{mol}\right)$ depend on whether the strains grow on sucrose or raffinose as carbon source (Malang et al., 2015). The most remarkable difference among HoPS, specially inulin-like fructan and FOS or inulin is precisely the size, which directly correlates to their degree of polymerization (DP); FOS and inulin are short oligosaccharides (DP $<30$, MW $\sim 5 \mathrm{kDa}$ ) while HoPS are branched polymers of high MW $(\sim 1,000 \mathrm{kDa}$; Salazar et al., 2015).

\section{Heteropolysaccharides}

Heteropolysaccharides from LAB were extensively studied at structural, genetic, and functional levels by Jolly and Stingele (2001) and Ruas-Madiedo and de los Reyes-Gavilán (2005).

In contrast to HoPS, HePS are complex polymers composed of a backbone of repeating subunits, branched or unbranched, that consist of three to eight monosaccharides, derivatives of monosaccharides or substituted monosaccharides. HePS usually contain D-glucose, D-galactose, and L-rhamnose although at different ratios. To a lesser extent, $N$-acetylated monosaccharides ( $N$-acetyl-glucosamine and $N$-acetyl-galactosamine), other monosaccharides (fucose, ribose) as well as organic and inorganic (glucuronic acid, acetyl groups, glycerol, phosphate, etc.) substituents (De Vuyst and Degeest, 1999; De Vuyst et al., 2001; Mozzi et al., 2006) can be found in some HePS. Inversely to HoPS, the HePS reapeating units are intracellularly synthesized, and polymerized outside the cell. More than 45 different repeating units have been described by NMR spectroscopy (De Vuyst et al., 2001; Broadbent et al., 2003; Ruas-Madiedo et al., 2009a), mostly of these corresponding to EPS synthesized by $\mathrm{LAB}$ and a few by bifidobacteria strains (Ruas-Madiedo et al., 2012). In accordance with this chemical diversity the enzymatic machinery involved in the synthesis of HePS as well as the genes encoding these enzymes, which are organized in eps clusters showing an operon-like structure, are much more complex than those of HoPS (Jolly and Stingele, 2001; Broadbent et al., 2003; Ruas-Madiedo et al., 2009a). These genes are organized in four functional regions involved in chain length determination, polymerization, export, and regulation of the gene cluster (van Kranenburg et al., 1997). Because of their different compositions and MW, HePS may vary in charge, spatial arrangements, rigidity, and the ability to interact with proteins (Duboc and Mollet, 2001). All these characteristics strongly affect the EPS physico-chemical properties, such as solubility, viscosity, etc., (Monchois et al., 1999). Noticeable, a common property of the HePS from LAB is the high thickening power displayed by some of them even at very low concentrations (Vaningelgem et al., 2004). This fact seems to be linked to the molar mass (MM) of the EPS rather than the biopolymer charge as suggested by Mende et al. (2013). Indeed, when equal amounts of EPS or CPS from S. thermophilus ST-143 were added to milk prior to acidification (induced by a chemical acidulant), the stiffness of the acidified milk gels increased almost linearly with the EPS concentration whereas the CPS concentration did not affect the rheology of the acidified gels when the same amounts of CPS and EPS were added. Both EPS fractions were determined to be uncharged but differed distinctly in their MM, which was $2.6 \times 10^{6} \mathrm{Da}$, and $1.4 \times 10^{5}$ and $7 \times 10^{3} \mathrm{Da}$ for the EPS and CPS, respectively (the latter one being composed of two fractions). In contrast, Pachekrepapol et al. (2015) found that the EPS charge positively influenced the rheology of acidified milk gels when using dextran and dextran-sulfate.

Regarding the HePS MW a broad range, varying from $10^{4}$ to $10^{6} \mathrm{Da}$, has been reported. Interestingly, simultaneous occurrence of more than one chromatographic peak of different size in polymers synthesized by a given strain is often frequent in these HePS (Mozzi et al., 2006; Ruas-Madiedo et al., 2009a; Salazar et al., 2009). The EPS MW is a property of special relevance for the technological functionality of the polymers that strongly influence the viscosity and texture of the matrix in which they are present. An increased use of specific methodologies such as Multi-Angle Laser Light Scattering (MALLS) coupled to a refractometer and NMR have been applied to obtain concluding 
results on EPS MW and structure in the last years (Shao et al., 2015). By this way, Laws et al. (2008) confirmed the presence of EPS showing three $\left(4,1.5\right.$, and $\left.1.3 \times 10^{5} \mathrm{Da}\right)$ and two $(2.5$ and $3.5 \times 10^{5} \mathrm{Da}$ ) peaks isolated from cultures of $L$. acidophilus $5 \mathrm{e} 2$ growing in skim milk or skim milk plus glucose, respectively. Both HePS consist of a heptasaccharide repeating unit containing $\mathrm{D}$-glucose, D-galactose and either $\mathrm{N}$-acetyl-D-glucosamine, or D-glucosamine. Simultaneous occurrence of more than one chromatographic peak of different size in HePS synthesized by L. rhamnosus KL37B was also reported (Górska-Fraçzek et al., 2013b). In this case, different repeating units (pentaand nona-saccharide, respectively) were found for each peak, both containing D-glucose and D-galactose (1:2 molar ratio). Pentasaccharide repeating units are present in HePS from L. johnsonii $151\left(1 \times 10^{5} \mathrm{Da}\right)$ and L. helveticus sp. Rosyjski $\left(1 \times 10^{6} \mathrm{Da}\right)$ containing D-glucose and D-galactose $(1: 1.5 \mathrm{molar}$ ratio) and D-glucose, D-galactose, and $\mathrm{N}$-acetyl-D-mannosamine (2:2:1 molar ratio), respectively, (Górska-Fraçzek et al., 2013a; Patten et al., 2014).

In general, the HePS production levels reported for LAB are lower than those for HoPS. It has been observed that EPS-production is strain-dependent and is strongly affected by the microbial culture conditions such as the composition of the culture medium, $\mathrm{pH}$, temperature, incubation time, etc., (Ruas-Madiedo and de los Reyes-Gavilán, 2005; Torino et al., 2005). Nevertheless, the use of different methods to isolate and quantify the HePS production makes difficult to compare yields accurately. To overcome this issue, methodologies for improving the purity of EPS and thus, to minimize variability in the methods were applied (Leemhuis et al., 2013b; Polak-Berecka et al., 2013). $\mathrm{HePS}$ yield values reported in the literature oscillate from 25 to $600 \mathrm{mg} / \mathrm{L}$ (Ruas-Madiedo et al., 2009b) while only a few strains have been reported to produce higher amounts under optimized growth conditions being the EPS yield $(2 \mathrm{~g} / \mathrm{L})$ obtained with L. rhamnosus RW-9595M the highest reported to date (Bergmaier et al., 2005). Within the S. thermophilus species, Vaningelgem et al. (2004) reported HePS yields varying from 20 to $600 \mathrm{mg} / \mathrm{L}$ in milk-based medium under optimal culture conditions. Zisu and Shah (2003) reported the highest EPS production $(1029 \mathrm{mg} / \mathrm{L})$ for the strain S. thermophilus ASCC 1275 (ST 1275) in milk medium supplemented with $0.5 \%(\mathrm{w} / \mathrm{v})$ whey protein concentrate (Zisu and Shah, 2003); this strain producing both CPS and ropy EPS (Zisu, 2005).

\section{Methodological Approaches}

The structural analysis and yields of any EPS start with the isolation of pure polymers. In this regard, one of the most important issues is to avoid EPS contamination with components from microbial culture medium, usually mannancontaining yeast extract. Different EPS isolation protocols have been reported all of them including: (i) cell removal by centrifugation or filtration, (ii) polymer precipitation from the cell-free supernatant by the addition of chilled ethanol or acetone (the amounts needed to achieve the recovery of the EPS depended on the type of polymer released; two or three volumes are usually used), (iii) dialysis and drying of the precipitated polymer, and eventually (iv), a new reprecipitation and dialysis step (Ruas-Madiedo and de los Reyes-Gavilán, 2005). Purification of EPS can also include membrane-filtration, anionexchange and/or gel permeation chromatography (Sanz and Martinez-Castro, 2007). In general, EPS isolation from highprotein content culture media (e.g., dairy products), proteins are typically removed by (i) precipitation with trichloroacetic acid, (ii) hydrolysis with proteases, (iii) or a combination of both.

Exopolysaccharides concentration is estimated as neutral carbohydrate content usually determined by the phenolsulphuric acid method (Dubois et al., 1956) or by weighting the polymer dry matter (Vaningelgem et al., 2004). In addition, EPS concentration can be determined by means of high-performance size exclusion chromatography coupled with refractive index (RI) detection (HPSEC-RI); EPS concentration is calculated by the integration of the RI signal using calibration curves obtained with known MW dextrans (Sánchez et al., 2006).

Recently, Polak-Berecka et al. (2013) compared EPS yields using different extraction procedures. The authors found that a sample heat treatment as first step in the EPS isolation is critical for its complete recovery, especially when CPS or EPS-degrading enzymes are present. In addition, they assumed that centrifugal forces over $10,000 \times g$ are too high being likely that part of the EPS is discarded together with the cell pellet. Considering the precipitation step, better results when prolonging the ethanol incubation $\left(24 \mathrm{~h}\right.$ at $\left.4^{\circ} \mathrm{C}\right)$ under stirring were obtained. Goh et al. (2005) found that $70 \%(\mathrm{v} / \mathrm{v})$ was sufficient to precipitate all dextran $\left(2 \times 10^{6} \mathrm{Da}\right)$ present in a sample while centrifugation regimes after the ethanol precipitation step should last 30-40 $\mathrm{min}$ at $27,000-28,000 \times g$.

Capsular polysaccharides can be visualized by light microscopy after negative staining with Indian ink as described by Mozzi et al. (1995); thus, a white polysaccharide layer surrounding the cells can be observed. In addition, Malang et al. (2015) used crystal violet to stain the cells blue facilitating the differentiation of CPS negative cells on dark background. CPS isolation can be done by harvesting $24 \mathrm{~h}$-cells, washing and resuspending them in $1 / 10$ of the initial volume. Then, cell suspensions are heated at $90{ }^{\circ} \mathrm{C}$ for $15 \mathrm{~min}$ to detach cell bound polysaccharides (Mende et al., 2013). Cells are removed by centrifugation ( $15 \mathrm{~min}, 12,000 \times g)$ and CPS are isolated from supernatants as described earlier for EPS.

As mentioned before, the major improvements in EPS characterization have been done related to techniques used for MW determination. Polymer MW was measuread based on the retention time of the polysaccharide eluted by HPSEC-RI; later, an increased use of HPSEC-MALLS was observed (Picton et al., 2000). In a higher degree of specificity or complexity, field flow fractionation (FFF) and hydrodynamic chromatography (HDC) can be used for determining the average MW of ultrahigh-MM polysaccharides (Cave et al., 2009; Isenberg et al., 2010; Galle et al., 2012b). Moreover, asymmetrical flow field fractionation (AF4) was successfully applied for the separation of starch-like glucans. Both, HPSEC and AF4, coupled with multiple inline detection of scattering intensities and mass profiles, provide 
distributions of apparent MW and radius of gyration with respect to the separated fractions (Rolland-Sabate et al., 2007; Juna et al., 2011).

The EPS monomer composition can be determined by total acid hydrolysis followed by monomer detection using high performance anion exchange chromatography (HPAEC) with pulsed amperometric detection (PAD; Cataldi et al., 2000). Alternatively, methanolysis and pertrimethylsilylation provide samples that can be analyzed by gas chromatography (GC). In addition, the monosaccharide analysis is used to determine the carbohydrate content, verifying the purity of the sample. The D or L configuration of the monosaccharide residues can be established by GC of the corresponding (-) 2-butyl glycosides (Gerwig et al., 1979). The linkage pattern of the monosaccharide constituents is determined after methylation of all free hydroxyl groups, followed by polymer hydrolysis, and further reduction of the monomers to alditols by sodium borodeuteride. Subsequent acetylation provides deuterated partially methylated alditol acetates that are analyzed by GC coupled with EI-MS (Ciucanu and Kerek, 1984). The percentages (ratio) of the terminal, internal, and branched glucose units as determined by the methylation analysis provides an idea of the polymer structure. Additional information about the structural features of the EPS can be obtained by ${ }^{1} \mathrm{H}$ and ${ }^{13} \mathrm{C}$ NMR spectroscopy. High-resolution NMR spectroscopy is the most powerful method for the unambiguous identification of carbohydrate chains (Damager et al., 2010). This method provides information of the type of constituent monosaccharides, ring size, and anomeric configuration, and the position of glycosidic linkages.

\section{Role of EPS-Producing LAB and their Polymers}

Generally, LAB divert a small percentage of their sugar substrates toward the EPS synthesis, whose main biological function in vivo has not been exactly established. However, it has been reported that EPS may help to protect bacterial cells against harsh environmental conditions (i.e., desiccation, heat or acidic stresses, phage attack) and the presence of adverse compounds (i.e., antibiotics, human gastric and pancreatic enzymes, bile salts; Ozturk et al., 2009; Stack et al., 2010; Lebeer et al., 2011). In addition, EPS are involved in biofilm formation, host-pathogen interactions, and cellular recognition (Kumar et al., 2007; Gänzle and Schwab, 2009; Chapot-Chartier et al., 2011). Moreover, it has been claimed that EPS may play a role in the adhesion to surfaces such as eukaryotic cells (plants, human intestinal cells) and in the host immune system modulation (Russo et al., 2012; Salazar et al., 2015).

In biofilm formation, EPS production enhances local accumulation of microbes enmeshing them in the insoluble biofilm matrix (Koo et al., 2013). Dental plaque represents the best-known example of microbial biofilm whose formation begins with the adhesion of oral bacteria to the tooth surface. In the complex microbiome, S. mutans is the major EPS producer when sucrose and starch are present in the diet, favoring the in situ polymer (glucans and fructans) biosynthesis (Paes Leme et al., 2006; Bowen and Koo, 2011).

Krinos et al. (2001) demonstrated that like CPS, EPS can affect the surface antigenicity of different strains resulting in maintenance or elimination of specific strains in the gut ecological niche (Ruas-Madiedo et al., 2009b; Pessione, 2012). Welman and Maddox (2003) stated that EPS may create biofilms aiding in the colonization of the gut by increasing the gut-transit time of LAB. On the other hand, some EPS-producing LAB involved in alcoholic beverage spoilage causing 'ropy' textural alterations have been shown to be resistant to lysozyme treatment (Coulon et al., 2012).

Other studies failed to reveal a significant phage resistant phenotype in EPS and CPS producer strains (Deveau et al., 2002; Rodriguez et al., 2008); in contrast, McCabe et al. (2015) recently reported on the targeted recognition of Lactococcus lactis phages to their polysaccharide receptors.

In addition, it has been hypothesized that EPS may play a role as extracellular energy/carbon reserve; however, most EPS producer species lack the genes involved in their own EPS degradation (Badel et al., 2011). EPS could be useful as carbon reserve in the case of sintrophyc/symbiotic life with other bacteria, considering the overall population. Thus, glucans and fructans formed by oral streptococci and lactobacilli have major influences on the formation of dental plaque since they are involved in adherence of bacteria to each other and to the tooth surface serving as extracellular energy reserves to the non-lactic biota (Russell, 1994; Colby et al., 1995). However, Russo et al. (2012) observed a positive effect on the growth of L. plantarum WCFS1 and L. acidophilus NCFM in a glucose-containing chemically defined medium by the $\beta$-D-glucan isolated from $P$. parvulus 2.6, although the EPS alone did not serve as carbon source.

Interestingly, while EPS are synthesized by certain LAB species (i.e., S. mutans) under quorum-sensing control (related with biofilm formation and adhesion to solid surfaces; Kumar et al., 2007; He et al., 2015), in L. reuteri strains EPS formation has been demonstrated to be induced by environmental stress (Hüfner et al., 2008).

\section{Applications of EPS from LAB in the Food Industry}

Exopolysaccharides from $\mathrm{LAB}$ have received special attention as valuable compounds because of their potential economic applications that include natural, safe-food additives or natural functional food ingredients increasing the possibility to replace or reduce the use of external hydrocolloids (Giraffa, 2004; Tieking et al., 2005a; Leemhuis et al., 2013a).

The large diversity of LAB species frequently isolated from raw materials and traditionally fermented foods (Van der Meulen et al., 2007; Endo et al., 2009; Robert et al., 2009; Ayeni et al., 2011; Shukla and Goyal, 2011; Di Cagno et al., 2013) has been the source of strains with interesting functionalities. In this sense, a wide diversity of EPS and genes encoding biosynthetic enzymes from naturally occurring LAB in fermented 
foods and beverages have been extensively studied for their role in the physicochemical (viscosifying, stabilizing, or waterbinding capacities) and sensorial (palatability) characteristics in the final food products. A remarkable structural diversity of EPS produced by Lactobacillus, Leuconostoc, and Weissella strains has been reported (Uzochukwu et al., 2001; OlivaresIllana et al., 2003; Di Cagno et al., 2006; Mozzi et al., 2006; van Hijum et al., 2006; Van der Meulen et al., 2007; Bounaix et al., 2010a,b; Amari et al., 2012; Dimopoulou et al., 2014; Grosu-Tudor and Zamfir, 2014). With exception of dextran synthesized by Leuc. mesenteroides, EPS from LAB have not yet been commercially exploited as food additive due to their low yields (Monsan et al., 2001); nonetheless, the structural characteristics of EPS and the GRAS status of most of the LAB EPS producer strains allow considering the in situ production of texturing and/or biologically active EPS (Badel et al., 2011).

\section{Fermented Milks and Beverages}

The use of EPS-producing cultures in the elaboration of fermented milks and beverages has been applied to reduce the amount of added milk solids, to improve the viscosity, texture, stability, and mouthfeel of the final products as well as to avoid syneresis (whey separation) during fermentation or upon storage (De Vuyst et al., 2001). Rheological problems like low viscosity, gel fracture or high syneresis are frequently encountered during fermented milk manufacture and can be solved by using EPSproducing LAB strains.

The contribution of the HePS to structure/function relationships is very complex. It has been postulated for example, that for high intrinsic viscosities stiffer chains, as the case of $\beta-(1,4)$ linkages, are required, which in turn lead to higher consistency of the EPS solutions. In addition, the degree of branching may contribute to the stiffness of the polymer and while the complexity of the primary structure (namely size, monomer composition, and side groups, $\alpha$ - and $\beta$-linkages, branching) influence the viscosity of EPS solutions (Tuinier et al., 2001). As no clear-cut relationships of EPS yields and functional properties exist, a rational selection of the EPS-producing LAB strains for the production of yogurt and other fermented milks should be considered to increase the viscosity and texture of the final product through in situ EPS production. This was the case for the yogurt $S$. thermophilus EPS-producing strains (Vaningelgem et al., 2004).

Certain fermented beverages owe their organoleptic and sensorial characteristics to the presence of $\mathrm{LAB}$ and the in situ EPS production during the elaboration of the fermented drinks as kefir and Pulque (Table 2).

Kefir is a viscous, slightly carbonated and alcoholic dairy beverage, traditionally consumed in Eastern European countries. Kefir is produced by bacteria and yeasts contained in kefir grains that have unique taste and properties. During fermentation, peptides, and EPS showing bioactive characteristics are formed. Kefiran is a water-soluble EPS produced in kefir grains, which consist of a complex population of $\mathrm{LAB}$ and yeasts firmly embedded (Cheirsilp et al., 2003). The principal kefiran producers in kefir grains is L. kefiranofaciens and several other unidentified species of lactobacilli. Kefiran is a branched glucogalactan composed of hexa- or heptasaccharide repeating structure with almost equal amounts of glucose and galactose

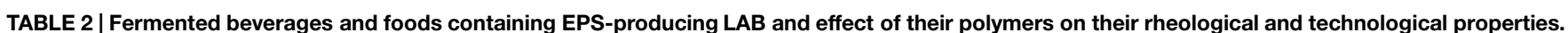

\begin{tabular}{|c|c|c|c|}
\hline $\begin{array}{l}\text { Fermented foods and } \\
\text { beverages }\end{array}$ & EPS-producing microorganisms & Sensorial attributes & Reference \\
\hline \multicolumn{4}{|l|}{ Fermented beverages } \\
\hline Yogurt & $\begin{array}{l}\text { S. thermophilus; L. delbrueckii subsp. } \\
\text { bulgaricus }\end{array}$ & $\begin{array}{l}\text { Increase in viscosity and texture improvement } \\
\text { of fermented milks and beverages }\end{array}$ & $\begin{array}{l}\text { De Vuyst et al., 2003; } \\
\text { Vaningelgem et al., } 2004\end{array}$ \\
\hline Kefir & L. kefiranofaciens & & $\begin{array}{l}\text { Maeda et al., 2004; } \\
\text { Wang et al., } 2008\end{array}$ \\
\hline Mexican Pulque & Leuc. mesenteroides & & Escalante et al., 2008 \\
\hline \multicolumn{4}{|l|}{ Cheeses } \\
\hline $\begin{array}{l}\text { Low-fat Italian } \\
\text { Cacciotta type }\end{array}$ & S. thermophilus & $\begin{array}{l}\text { Pleasant to taste and chew, flavor, overall } \\
\text { acceptability }\end{array}$ & Di Cagno et al., 2014 \\
\hline Egyptian Karish & & $\begin{array}{l}\text { Enhanced acceptability, spreadability, and } \\
\text { creaminess }\end{array}$ & Hassan et al., 2004 \\
\hline Reduced-fat & S. thermophilus TM11 & Increased moisture content and high yield & Wang et al., 2012 \\
\hline Mexican Chihuahua & EPS-producing starter culture & Improved cheese yield and texture & Trancoso-Reyes et al., 2014 \\
\hline Reduced-fat Cheddar & & Improved body and texture & Agrawal and Hassan, 2008 \\
\hline \multicolumn{4}{|l|}{ Fermented Breads } \\
\hline Gluten-free breads & $\begin{array}{l}\text { W. cibaria; W. confusa; Leuc. } \\
\text { mesenteroides; L. sanfranciscensis }\end{array}$ & Enhanced texture and quality & $\begin{array}{l}\text { Schwab et al., 2008; } \\
\text { Galle et al., 2012a; } \\
\text { Rühmkorf et al., 2012; } \\
\text { Wolter et al., 2014a,b }\end{array}$ \\
\hline Gluten-free sorghum & $\begin{array}{l}\text { L. casei FUA3185 and FUA3186, L. } \\
\text { buchneri FUA3154 }\end{array}$ & Improved rheology of sorghum sourdoughs & Galle et al., 2011 \\
\hline Wheat & Leuc. lactis, L. curvatus & Improved viscoelasticity and quality & Palomba et al. (2012) \\
\hline
\end{tabular}


(Maeda et al., 2004; Medrano et al., 2009). The MW of kefiran obtained from kefir grain has been reported as higher than $10^{7}$ Da by Piermaria et al. (2008) while Maeda et al. (2004) found a MW value of $7.6 \times 10^{5}$ when culturing the single strain L. kefiranofaciens WT-2B(T) isolated from kefir grain in liquid medium containing a rice hydrolysate.

Pulque is a traditional Mexican, non-distilled alcoholic fermented beverage consumed mainly in Central Mexico. It is obtained from the fermentation of a fresh sap known as aguamiel, which is extracted from different Agave species. Freshly collected aguamiel is deposited in open containers where previously fermented pulque acts as seed for a new batch. Fermentation time varies from a few hours to several days. The viscosity resultant from EPS synthesis and the alcoholic content of the beverage are features used to determine the extent of fermentation and the sensorial properties of pulque (Escalante et al., 2008). Among LAB, Leuc. mesenteroides has been traditionally considered one of the most important microorganisms during pulque fermentation due to its ability to synthesize dextrans from sucrose present in aguamiel and pulque. The structure of an EPS produced by the strain Leuc. mesenteroides IBT-PQ isolated from pulque revealed the presence of a soluble linear dextran with glucose molecules linked by $\alpha-(1,6)$ bonds with branching from $\alpha-(1,3)$ bonds in a 4:1 ratio, respectively. A great LAB diversity in aguamiel and pulque samples from different geographical origins, composed mainly of Lactobacillus and Leuconostoc species, has been reported (Escalante et al., 2004). Leuc. citreum and L. kimchii were reported to be the most abundant LAB species present in aguamiel during the early stages of pulque fermentation (Escalante et al., 2008).

\section{Cheeses}

It has been reported that EPS-producing LAB improve the sensory attributes of various cheeses, especially those reducedand low-fat varieties where the decrease in the fat content negatively affects the textural and meltability properties of cheese (Table 2). In this sense, the application of EPS-producing strains for improving the texture and technical properties of reducedfat cheese has been very promising. EPS produced by non-ropy strains have drawn the attention of the dairy industry since their ability to produce CPS and EPS could improve the texture of dairy products without causing the undesirable slippery mouthfeel produced by the ropy strains (Hassan, 2008).

Recently, Di Cagno et al. (2014) used an EPS-producing S. thermophilus strain to produce low-fat Italian Caciotta-type cheese. The sensory attributes of cheeses containing the EPSproducing strain were pleasant to taste and to chew, showed intensity of flavor, and overall acceptability. Based on these observations, 14-day ripened low-fat Caciotta-type cheese had promising features to be further exploited as a suitable alternative to the full-fat variant.

Costa et al. (2010) found that reduced-fat Cheddar cheese made with an EPS-producing Lactococcus lactis strain displayed an $8.2 \%$ increase in yield (per $100 \mathrm{~kg}$ of milk), 9.5\% increase in moisture content, and increase in water activity and water desorption rate. Interestingly, the presence of EPS did not negatively affect the flavor profile of the cheese.
Agrawal and Hassan (2008) studied the technological characteristics of reduced-fat Cheddar cheese made with ultrafiltrated (UF) milk and an EPS-producing culture. The authors observed that UF did not affect the hardness, cohesiveness, adhesiveness, chewiness, and gumminess of the EPS-containing cheese while the springiness of the EPScontaining cheese made from UF milk was much lower than that of the non-EPS cheeses. Texture of the EPS-negative cheese was more affected by UF than the EPS-positive cheese. While UF increased the elastic modulus in the 6-month old EPSpositive cheeses, higher body, and texture scores were given to EPS-positive cheeses than to EPS-negative ones.

Hassan et al. (2004) reported that the inclusion of EPSproducing cultures in the traditional Egyptian cheese Karish enhanced consumer acceptability by improving their spreadability and creaminess. This product is conventionally produced by adding fat, sugar, protein or stabilizers like pectin, starch, alginate or gelatin; thus, the addition of EPS cultures could be an interesting and viable alternative to the use of exogenous polysaccharides. Moreover, EPS from LAB may prolong the retention time of the milk product in the mouth, enhancing its delicacy.

More recently, Trancoso-Reyes et al. (2014) observed that the addition of EPS alone improved the Mexican Chihuahua cheese yield by increasing water and fat retention, causing, however, a negative effect on the texture and flavor of the cheese. When authors used the EPS-producing bacteria in combination with a phospholipase-A1 (PL-A1)-producing strain, an improvement on cheese yield, moisture, and fat content was observed. The cheeses showing the best flavor and texture were those manufactured with PL-A1 and with the combination of PL-A1 and the EPS-producing culture.

In addition, the EPS-producing strain $S$. thermophilus TM11 was evaluated for the production of reduced-fat cheese using reconstituted milk powder (Wang et al., 2012). The physicochemical analysis of fresh and stored cheeses showed that this strain slightly increased moisture content resulting in cheese with higher yield and lower protein content compared to the direct acidified cheese.

In summary, EPS provide functions that benefit reducedfat cheeses since they bind water and increase the moisture in the non-fat portion, interfere with protein-protein interactions, reduce the rigidity of the protein network, and increase viscosity of the serum phase (Hassan, 2008).

\section{Fermented Breads}

Grinding of cereals and addition of water results in the formation of a dough that after some time will turn into a sourdough with characteristic acidic taste, aroma and increased volume due to gas formation. Cereal fermentation goes back to ancient times as one of the early microbial processes employed by man leading to the use of sourdough for bread-making (Hammes and Gänzle, 1997). The sourdough process was rediscovered because of the effects on the sensory, structural, nutritional and shelf life properties of leavened baked goods (Arendt et al., 2007; Gobbetti et al., 2014). In sourdough fermentation LAB and yeast communities are involved; while $\mathrm{LAB}$ dominate the microbial community 
and are responsible for acid production, yeasts are responsible for dough leavening. $\mathrm{LAB}$ are involved in both decreasing the $\alpha$-amylase activity and improving dough texture. In addittion, sourdough LAB may synthesize a large variety of EPS through GS activity. Since these bacteria are used as starters in cereal fermentations, these polymers are available for food applications through the in situ biosynthesis during processing (Tieking and Gänzle, 2005; Bounaix et al., 2009).

Lactic acid bacteria able to produce HoPS are already applied in the elaboration of conventional bread (Lacaze et al., 2007); however, their use is more promising in gluten-free baking since EPS can potentially act as hydrocolloids improving their rheological properties (Schwab et al., 2008; Galle et al., 2012a; Rühmkorf et al., 2012).

It has been reported that microbial in situ production of EPS during sourdough fermentation is more effective than the addition of comparable amounts of EPS to the bread formulation. The ability to produce HoPS by LAB strains during sourdough fermentation depends on the metabolic activity of the fermentation microbiota (Gänzle et al., 2007), and contributes to the sourdough ability to influence bread quality (Katina et al., 2009; Galle et al., 2012a; Palomba et al., 2012). More recently, Gobbetti et al. (2014) have observed that the in situ EPS formation was responsible for the significant decrease of dough strength and elasticity; however, dextran produced showed the best shelf life improvement.

Dextran production from sucrose is a phenotypic identification characteristic of the $W$. confusa and $W$. cibaria species. Weisella strains have been used for in situ dextran and GOS synthesis to improve the texture and quality of wheat and gluten-free breads (Schwab et al., 2008; Katina et al., 2009; Galle et al., 2010, 2012a; Wolter et al., 2014a,b). In this sense, high MW dextrans are used in sourdough baking to produce good quality bread (Maina et al., 2011). Dextrans have displayed prebiotic potential (Olano-Martin et al., 2000) and have been already approved by the European Commission to be used as additive in bakery products.

Exopolysaccharides produced by certain lactobacilli, such as the $\beta$ - $(2,6)$ levan synthesized by the sourdough strain L. sanfranciscensis, positively influence bread textural properties by facilitating water absorption, softening the gluten content of

\section{References}

Abedin, R. M. A., El-Borai, A. M., Shall, M. A., and El-Assar, S. A. (2013). Optimization and statistical evaluation of medium components affecting dextran and dextransucrase production by Lactobacillus acidophilus ST76480.01. Life Sci. J. 10, 1746-1753.

Agrawal, P., and Hassan, A. N. (2008). Characteristics of reduced fat Cheddar cheese made from ultrafiltered milk with an exopolysaccharideproducing culture. J. Dairy Res. 75, 182-188. doi: 10.1017/S00220299080 03294

Aman, A., Siddiqui, N. N., and Qader, S. A. U. (2012). Characterization and potential applications of high molecular weight dextran produced by Leuconostoc mesenteroides AA1. Carbohyd. Polym. 87, 910-915. doi: 10.1016/j.carbpol.2011.08.094

Amari, M., Laguerre, S., Vuillemin, M., Robert, H., Loux, V., Klopp, C., et al. (2012). Genome sequence of Weissella confusa LBAE C39-2, isolated from a wheat sourdough. J. Bacteriol. 194, 1608-1609. doi: 10.1128/JB.06788-11 dough, improving the structure build-up, retarding bread staling and prolonging shelf life (Tieking and Gänzle, 2005).

In the traditional Italian sweet bread panettone, dextran produced by a Leuc. mesenteroides strain was responsible for the long storage stability (Decock and Cappelle, 2005). In this product, dextran production was optimized by transferring the doughs seven times. In sweet wheat milk bread, a remarkable reduction in bread firmness along the storage period was obtained (Lacaze et al., 2007).

As mentioned above, EPS isolated from sourdough include mainly HoPS; however, Van der Meulen et al. (2007) reported the production of HePS from a sourdough isolate strain of L. curvatus, which synthesized an EPS composed of galactosamine, galactose, and glucose in a ratio of 2:3:1, respectively. In addition, Galle et al. (2011) have investigated the influence of HePS-producing LAB in sourdough fermentation and found that the use of this type of EPS positively affected the rheological properties of sorghum sourdough, expanding the diversity of EPS and the variety of cultures used for baking.

\section{Concluding Remarks}

Exopolysaccharides-producing LAB hold great potential for the functional food sector either as starter and adjunct cultures or as in situ supplier of bioactive polymers with positive impact on the rheology of fermented products or on the human health. The increased knowledge concerning the enzymes involved in HoPS synthesis and their regulation open new possibilities for their use to improve the texture of sucrose-supplemented products. Most of the research done on EPS during the last decade was focused on the evaluation of HoPS structures as well as the novel functionalities of HePS. In this concern, the requirement of specific methodologies (FTIR, NMR, MALLS, FFF, AF4, etc.) for the EPS structural analysis as well as the ex vivo assays (cell tissues) to determine their biological activity was essential. Nevertheless, the structure/function relationships of EPS should be in situ proved in foods or other matrices of interest. The improvement of EPS production to reduce their industrial costs and the design of tailor-made EPS with desired/specific functionalities remain challenging.

Anwar, M. A., Kralj, S., Pique, A. V., Leemhuis, H., van der Maarel, M. J. E. C., and Dijkhuizen, L. (2010). Inulin and levan synthesis by probiotic Lactobacillus gasseri strains: characterization of three novel fructansucrase enzymes and their fructan products. Microbiology 156, 1264-1274. doi: 10.1099/mic.0.036 616-0

Anwar, M. A., Kralj, S., van der Maarel, M. J., and Dijkhuizen, L. (2008). The probiotic Lactobacillus johnsonii NCC 533 produces high-molecular-mass inulin from sucrose by using an inulosucrase enzyme. Appl. Environ. Microbiol. 74, 3426-3433. doi: 10.1128/AEM.00377-08

Arendt, E. K., Ryan, L. A. M., and Dal Bello, F. (2007). Impact of sourdough on the texture of bread. Food Microbiol. 24, 165-174. doi: 10.1016/j.fm.2006. 07.011

Ayeni, F. A., Sánchez, B., Adeniyi, B. A., de Los Reyes-Gavilán, C. G., Margolles, A., and Ruas-Madiedo, P. (2011). Evaluation of the functional potential of Weissella and Lactobacillus isolates obtained from Nigerian traditional fermented foods and cow's intestine. Int. J. Food Microbiol. 147, 97-104. doi: 10.1016/j.ijfoodmicro.2011.03.014 
Badel, S., Bernardi, T., and Michaud, P. (2011). New perspectives for Lactobacilli exopolysaccharides. Biotechnol. Adv. 29, 54-66. doi: 10.1016/j.biotechadv.2010.08.011

Bejar, W., Gabriel, V., Amari, M., Morel, S., Mezghani, M., Maguin, E., et al. (2013). Characterization of glucansucrase and dextran from Weissella sp. TN610 with potential as safe food additives. Int. J. Biol. Macromol. 52, 125-132. doi: 10.1016/j.ijbiomac.2012.09.014

Bergmaier, D., Champagne, C. P., and Lacroix, C. (2005). Growth and exopolysaccharide production during free and immobilized cell chemostat culture of Lactobacillus rhamnosus RW-9595M. J. Appl. Microbiol. 98, 272-284. doi: 10.1111/j.1365-2672.2004.02462.x

Boguta, A. M., Bringel, F., Martinussen, J., and Jensen, P. R. (2014). Screening of lactic acid bacteria for their potential as microbial cell factories for bioconversion of lignocellulosic feedstocks. Microb. Cell Fact. 13, 97. doi: 10.1186/s12934-014-0097-0

Borges, S., Silva, J., and Teixeira, P. (2014). The role of lactobacilli and probiotics in maintaining vaginal health. Arch. Gynecol. Obstet. 289, 479-489. doi: 10.1007/s00404-013-3064-9

Bounaix, M. S., Gabriel, V., Morel, S., Robert, H., Rabier, P., Remaud-Siméon, M., et al. (2009). Biodiversity of exopolysaccharides produced from sucrose by sourdough lactic acid bacteria. J. Agric. Food Chem. 57, 10889-10897. doi: $10.1021 / \mathrm{j} 902068 \mathrm{t}$

Bounaix, M. S., Gabriel, V., Robert, H., Morel, S., Remaud-Siméon, M., Gabriel, B., et al. (2010a). Characterization of glucan-producing Leuconostoc strains isolated fromsourdough. Int. J. Food Microbiol. 144, 1-9. doi: 10.1016/j.ijfoodmicro.2010.05.026

Bounaix, M. S., Robert, H., Gabriel, V., Morel, S., Remaud-Siméon, M., Gabriel, B., et al. (2010b). Characterization of dextran-producing Weissella strains isolated from sourdoughs and evidence of constitutive dextransucrase expression. FEMS Microbiol. Lett. 311, 18-26. doi: 10.1111/j.1574-6968.2010.0 2067.x

Bowen, W. H., and Koo, H. (2011). Biology of Streptococcus mutans derived glucosyltransferases: role in extracellular matrix formation of cariogenic biofilms. Caries Res. 45, 69-86. doi: 10.1159/000324598

Brison, Y., Pijning, T., Malbert, Y., Fabre, E., Mourey, L., Morel, S., et al. (2012). Functional and structural characterization of an $\alpha-(1-2)$ branching sucrase derived from DSR-E glucansucrase. J. Biol. Chem. 287, 7915-7924. doi: 10.1074/jbc.M111.305078

Broadbent, J. R., McMahon, D. J., Welker, D. L., Oberg, C. J., and Moineau, S. (2003). Biochemistry, genetics and applications of exopolysaccharide production in Streptococcus thermophilus: a review. J. Dairy Sci. 86, 407-423. doi: 10.3168/jds.S0022-0302(03)73619-4

Cantarel, B. L., Coutinho, P. M., Rancurel, C., Bernard, T., Lombard, V., and Henrissat, B. (2009). The Carbohydrate-active enZymes database (CAZy): an expert resource for glycogenomics. Nucleic Acids Res. 37, D233-D238. doi: 10.1093/nar/gkn663

Cataldi, T. R., Campa, C., and De Benedetto, G. E. (2000). Carbohydrate analysis by high-performance anion-exchange chromatography with pulsed amperometric detection: the potential is still growing. Fresenius J. Anal. Chem. 368, 739-758. doi: $10.1007 / \mathrm{s} 002160000588$

Cave, R. A., Seabrook, S. A., Gidley, M. J., and Gilbert, R. G. (2009). Characterization of starch by size-exclusion chromatography: the limitations imposed by shear scission. Biomacromology 10, 2245-2253. doi: 10.1021/bm900426n

Chapot-Chartier, M.-P., Monnet, V., and De Vuyst, L. (2011). "Cell walls and exopolysaccharides of lactic acid bacteria," in The 10th LAB Symposium. Thirty Years Research on Lactic Acid Bacteria, eds A. Ledeboer, J. Hugenholtz, J. Kok, W. Konings, and J. Wouters (Rotterdam: Media Labs), 37-59.

Cheirsilp, B., Shimizu, H., and Shioya, S. (2003). Enhanced kefiran production by mixed culture of Lactobacillus kefiranofaciens and Saccharomyces cerevisiae. J. Biotechnol. 100, 43-53. doi: 10.1016/\$0168-1656(02)00228-6

Ciucanu, I., and Kerek, F. (1984). A simple and rapid method for the permethylation of carbohydrates. Carbohydr. Res. 131, 209-217. doi: 10.1016/0008-6215(84)85242-8

Colby, S. M., Withing, G. C., Tao, L., and Russell, R. R. B. (1995). Insertional inactivation of the Streptococcus mutans dexA (dextranase) gene results in altered adherence and dextran catabolism. Microbiology 141, 2929-2936. doi: 10.1099/13500872-141-11-2929
Costa, N. E., Hannon, J. A., Guinee, T. P., Auty, M. A., McSweeney, P. L., and Beresford, T. P. (2010). Effect of exopolysaccharide produced by isogenic strains of Lactococcus lactis on half-fat Cheddar cheese. J. Dairy Sci. 93, 3469-3486. doi: $10.3168 /$ jds.2009-3008

Coulon, J., Houlès, A., Dimopoulou, M., Maupeu, J., and Dols-Lafargue, M. (2012). Lysozyme resistance of the ropy strain Pediococcus parvulus IOEB 8801 is correlated with beta-glucan accumulation around the cell. Int. J. Food Microbiol. 159, 25-29. doi: 10.1016/j.ijfoodmicro.2012.07.024

Damager, I., Engelsen, S. B., Blennow, A., Moller, B. L., and Motawia, M. S. (2010). First principles insight into the $\alpha$-glucan structures of starch: their synthesis, conformation, and hydration. Chem. Rev. 110, 2049-2080 doi: $10.1021 / \mathrm{cr} 900227 \mathrm{t}$

Das, D., and Goyal, A. (2014). Characterization and biocompatibility of glucan: a safe food additive from probiotic Lactobacillus plantarum DM5. J. Sci. Food Agric. 94, 683-690. doi: 10.1002/jsfa.6305

De Vuyst, L., and Degeest, B. (1999). Heteropolysaccharides from lactic acid bacteria. FEMS Microbiol. Rev. 23, 153-177. doi: 10.1111/j.15746976.1999.tb00395.x

De Vuyst, L., de Vin, F., Vaningelgem, F., and Degeest, B. (2001). Recent development in thebiodsynthesis and applications of heteropolysaccharides from lactic acid bacteria. Int. Dairy J. 11, 687-707. doi: 10.1016/S09586946(01)00114-5

De Vuyst, L., Zamfir, M., Mozzi, F., Adriany, T., Marshall, V., Degeest, B., et al. (2003). Exopolysaccharide-producing Streptococcus thermophilus strains as functional starter cultures in the production of fermented milks. Int. Dairy J. 13, 707-717. doi: 10.1016/S0958-6946(03)00105-5

Decock, P., and Cappelle, S. (2005). Bread technology and sourdough technology. Trends Food Sci. Technol. 16, 113-120. doi: 10.1016/j.tifs.2004.04.012

Deveau, H., Van Calsteren, M. R., and Moineau, S. (2002). Effect of exopolysaccharides on phage-host interactions in Lactococcus lactis. Appl. Environ. Microbiol. 68, 4364-4369. doi: 10.1128/AEM.68.9.4364-4369.2002

Di Cagno, R., Coda, R., De Angelis, M., and Gobbetti, M. (2013). Exploitation of vegetables and fruits through lactic acid fermentation. Food Microbiol. 33, 1-10. doi: $10.1016 /$ j.fm.2012.09.003

Di Cagno, R., De Angelis, M., Limitone, A., Minervini, F., Carnevali, P., Corsetti, A., et al. (2006). Glucan and fructan production by sourdough Weissella cibaria and Lactobacillus plantarum. J. Agric. Food Chem. 54, 9873-9881. doi: 10.1021/jf061393+

Di Cagno, R., De Pasquale, I., De Angelis, M., Buchin, S., Rizzello, C. G., and Gobbetti, M. (2014). Use of microparticulated whey protein concentrate, exopolysaccharide-producing Streptococcus thermophilus, and adjunct cultures for making low-fat Italian Caciotta-type cheese. J. Dairy Sci. 97, 72-84. doi: $10.3168 /$ jds.2013-7078

Dimopoulou, M., Vuillemin, M., Campbell-Sills, H., Lucas, P. M., Ballestra, P., Miot-Sertier, C., et al. (2014). Exopolysaccharide (EPS) synthesis by Oenococcus oeni: from genes to phenotypes. PLoS ONE 5:e98898. doi: 10.1371/journal.pone.0098898

Dols-Lafargue, M., Lee, H. Y., Le Marrec, C., Heyraud, A., Chambat, G., and Lonvaud-Funel, A. (2008). Characterization of gtf, a glucosyltransferase gene in the genomes of Pediococcus parvulus and Oenococcus oeni, two bacterial species commonly found in wine. Appl. Environ. Microbiol. 74, 4079-4090. doi: 10.1128/AEM.00673-08

Duboc, P., and Mollet, B. (2001). Applications of exopolysaccharides in the dairy industry. Int. Dairy J. 11, 759-768. doi: 10.1016/S0958-6946(01)00 119-4

Dubois, M., Gilles, K. A., Hamilton, J. K., Rebers, P. A., and Smith, F. (1956). Colorimetric method for the determination of sugars and related substances. Anal. Chem. 28, 350-356. doi: 10.1021/ac60111a017

Dueñas-Chasco, M. T., Rodríguez-Carvajal, M. A., Mateo, P. T., FrancoRodríguez, G., Espartero, J. L., Irastorza-Iribas, A., et al. (1997). Structural analysis of the exopolysaccharide produced by Pediococcus damnosus 2.6. Carbohydr. Res. 303, 453-458. doi: 10.1016/S0008-6215(97) 00192-4

Dueñas-Chasco, M. T., Rodríguez-Carvajal, M. A., Tejero-Mateo, P., Espartero, J. L., Irastorza-Iribas, A., and Gil-Serrano, A. M. (1998). Structural analysis of the exopolysacharide produced by Lactobacillus spp. G-77. Carbohydr. Res. 307, 125-133. doi: 10.1016/S0008-6215(98)00034-2

EFSA. (2010). What's New on Novel Foods? Amsterdam: EFSA. 
Endo, A., Futagawa-Endo, Y., and Dicks, L. M. (2009). Isolation and characterization of fructophilic lactic acid bacteria from fructose-rich niches. Syst. Appl. Microbiol. 32, 593-600. doi: 10.1016/j.syapm.2009. 08.002

Escalante, A., Giles-Gómez, M., Hernández, G., Córdova-Aguilar, M. S., LópezMunguía, A., Gosset, G., et al. (2008). Analysis of bacterial community during the fermentation of pulque, a traditional Mexican alcoholic beverage, using a polyphasic approach. Int. J. Food. Microbiol. 124, 126-134. doi: 10.1016/j.ijfoodmicro.2008.03.003

Escalante, A., Rodríguez, M. E., Martínez, A., López-Munguía, A., Bolívar, F., and Gosset, G. (2004). Characterization of bacterial diversity in pulque, a traditional Mexican alcoholic fermented beverage, as determined by 16S rDNA analysis. FEMS Microbiol. Lett. 235, 273-279. doi: 10.1111/j.1574-6968.2004.tb09 599.x

Foligné, B., Daniel, C., and Pot, B. (2013). Probiotics from research to market: the possibilities, risks and challenges. Curr. Opin. Microbiol. 16, 284-292. doi: 10.1016/j.mib.2013.06.008

Fujiwara, T., Hoshino, T., Ooshima, T., Sobue, S., and Hamada, S. (2000) Purification, characterization, and molecular analysis of the gene encoding glucosyltransferase from Streptococcus oralis. Infect. Immun. 68, 2475-2483. doi: 10.1128/IAI.68.5.2475-2483.2000

Galle, S., and Arendt, E. K. (2014). Exopolysaccharides from sourdough lactic acid bacteria. Crit. Rev. Food Sci. Nutr. 54, 891-901. doi 10.1080/10408398.2011.617474

Galle, S., Schwab, C., Arendt, E., and Gänzle, M. (2010). Exopolysaccharideforming Weissella strains as starter cultures for sorghum and wheat sourdoughs. J. Agric. Food Chem. 58, 5834-5841. doi: 10.1021/jf10 02683

Galle, S., Schwab, C., Arendt, E. K., and Gänzle, M. G. (2011). Structural and rheological characterisation of heteropolysaccharides produced by lactic acid bacteria in wheat and sorghum sourdough. Food Microbiol. 28, 547-553. doi: 10.1016/j.fm.2010.11.006

Galle, S., Schwab, C., Dal Bello, F., Coffey, A., Gänzle, M. G., and Arendt, E. K. (2012a). Influence of in-situ synthesized exopolysaccharides on the quality of gluten-free sorghum sourdough bread. Int. J. Food Microbiol. 155, 105-112. doi: 10.1016/j.ijfoodmicro.2012.01.009

Galle, S., Schwab, C., Dal Bello, F., Coffey, A., Gänzle, M., and Arendt, E. (2012b). Comparison of the impact of dextran and reuteran on the quality of wheat sourdough bread. J. Cereal Sci. 56, 531-537. doi: 10.1016/j.jcs.2012. 07.001

Gänzle, M., and Schwab, C. (2009). "Ecology of exopolysaccharide formation by lactic acidbacteria: sucrose utilization, stress tolerance and biofim formation", in Bacterial Polysaccharides, Current Innovations and Future Trends, ed. M. Ullrich (Norfolk: Caister Academic Press), 263-278.

Gänzle, M. G., Vermeulen, N., and Vogel, R. F. (2007). Carbohydrate, peptide and lipid metabolism of lactic acid bacteria in sourdough. Food Microbiol. 24, 128-138. doi: 10.1016/j.fm.2006.07.006

Garai-Ibabe, G., Dueñas, M. T., Irastorza, A., Sierra-Filardi, E., Werning, M. L., López, P., et al. (2010). Naturally occurring 2-substituted (1,3)-beta-dglucan producing Lactobacillus suebicus and Pediococcus parvulus strains with potential utility in the production of functional foods. Biores. Technol. 101, 9254-9263. doi: 10.1016/j.biortech.2010.07.050

Gaspar, P., Carvalho, A. L., Vinga, S., Santos, H., and Neves, A. R. (2013) From physiology to systems metabolic engineering for the production of biochemicals by lactic acid bacteria. Biotechnol. Adv. 31, 764-788. doi: 10.1016/j.biotechadv.2013.03.011

Gerwig, G. J., Kamerling, J. P., and Vliegenthart, J. F. (1979). Determination of the absolute configuration of mono-saccharides in complex carbohydrates by capillary G.L.C. Carbohyd. Res. 77, 10-17 doi: 10.1016/S0008-6215(00)83 788-X

Giraffa, G. (2004). Studying the dynamics of microbial populations during food fermentation. FEMS Microbiol. Rev. 28, 251-260. doi: 10.1016/j.femsre.2003.10.005

Gobbetti, M., Rizzello, C. G., Di Cagno, R., and De Angelis, M. (2014). How the sourdough may affect the functional features of leavened baked goods. Food Microbiol. 37, 30-40. doi: 10.1016/j.fm.2013.04.012

Goh, K. K. T., Haisman, D. R., Archer, R. H., and Singh, H. (2005). Evaluation and modification of existing methods for the quantification of exopolysaccharides in milk-based media. Food Res. Int. 38, 605-613. doi: 10.1016/j.foodres.2004.11.014

Górska-Fraçzek, S., Sandström, C., Kenne, L., Pásciak, M., Brzozowska, E., Strus, M., et al. (2013a). The structure and immunoreactivity of exopolysaccharide isolated from Lactobacillus johnsonii strain 151. Carbohydr. Res. 378, 148-153. doi: 10.1016/j.carres.2013.05.012

Górska-Fraçzek, S., Sandström, C., Kenne, L., Rybka, J., Strus, M., Heczko, P., et al. (2013b). Structural studies of the exopolysaccharide consisting of a nonasaccharide repeating unit isolated from Lactobacillus rhamnosus KL37B. Carbohydr. Res. 346, 2926-2932. doi: 10.1016/j.carres.2011.10.024

Grosu-Tudor, S. S., and Zamfir, M. (2014). Exopolysaccharide production by selected lactic acid bacterias isolated from fermented vegetables. Sci. Bull. Ser. Biotechnol. XVIII, 107-114.

Hammes, W. P., and Gänzle, M. G. (1997). "Sourdough breads and related products", in Microbiology of Fermented Foods, eds E. Wood and J. B. Brian (Berlin: Springer), 199-216.

Hassan, A. N. (2008). Possibilities and challenges of exopolysaccharide-producing lactic culturesin dairy foods. J. Dairy Sci. 91, 1282-1298. doi: 10.3168/jds.20070558

Hassan, A. N., Corredig, M., Frank, J. F., and Elsoda, M. (2004). Microstructure and rheology of an acid-coagulated cheese (Karish) made with an exopolysaccharide-producing Streptococcus thermophilus strain and its exopolysaccharide non-producing genetic variant. J. Dairy Res. 71, 116-120. doi: 10.1017/S0022029903006605

He, Z., Liang, J., Tang, Z., Ma, R., Peng, H., and Huang, Z. (2015). Role of the luxS gene in initial biofilm formation by Streptococcus mutans. J. Mol. Microbiol. Biotechnol. 25, 60-68. doi: 10.1159/000371816

Hongpattarakere, T., Cherntong, N., Wichienchot, S., Kolida, S., and Rastall, R. A. (2012) In vitro prebiotic evaluation of exopolysaccharides produced by marine isolated lactic acid bacteria. Carbohydr. Polym. 87, 846-852. doi: 10.1016/j.carbpol.2011.08.085

Hüfner, E., Britton, R. A., Roos, S., Jonsson, H., and Hertel, C. (2008). Global transcriptional response of Lactobacillus reuteri to the sourdough environment. Syst. Appl. Microbiol. 31, 323-338. doi: 10.1016/j.syapm.2008.06.005

Hugenholtz, J. (2008). The lactic acid bacterium as a cell factory for food ingredient production. Int. Dairy J. 18, 466-475. doi: 10.1016/j.idairyj.2007.11.015

Ibarburu, I., Soria-Díaz, M. E., Rodríguez-Carvajal, M. A., Velasco, S. E., TejeroMateo, P., Gil-Serrano, A. M., et al. (2007). Growth and exopolysaccharide (EPS) production by Oenococcus oeni I4 and structural characterization of their EPSs. J. Appl. Microbiol. 103, 477-486. doi: 10.1111/j.1365-2672.2006. 03266.x

Isenberg, S. L., Brewer, A. K., Côté, G. L., and Striegel, A. M. (2010). Hydrodynamic versus size exclusion chromatography characterization of alternan and comparison to off-line MALS. Biomacromology 11, 2505-2511. doi: 10.1021/bm100687b

Ito, A., Hayashi, M., Hamasaki, T., and Ebisu, S. (2011). Risk assessment of dental caries by using Classification and Regression Trees. J. Dent. Res. 39, 457-463. doi: 10.1016/j.jdent.2011.04.002

Jolly, L., and Stingele, F. (2001). Molecular organization and functionality of exopolysaccharidegene cluster in lactic acid bacteria. Int. Dairy J. 11, 733-745. doi: 10.1016/S0958-6946(01)00117-0

Juna, S., Williams, P. A., and Davies, S. (2011). Determination of molecular mass distribution of amylopectin using asymmetrical flow field-flow fractionation. Carbohyd. Polym. 83, 1384-1396 doi: 10.1016/j.carbpol.2010.09.045

Kang, H.-K., Oh, J.-S., and Kim, D. (2009). Molecular characterization and expression analysis of the glucansucrase DSRWC from Weissella cibaria synthesizing a $\alpha-(1,6)$ glucan. FEMS Microbiol. Lett. 292, 33-41. doi: 10.1111/j.1574-6968.2008.01460.x

Katina, K., Maina, N. H., Juvonen, R., Flander, L., Johansson, L., Virkki, L., et al. (2009). In situ production and analysis of Weissella confusa dextran in wheat sourdough. Food Microbiol. 26, 734-743. doi: 10.1016/j.fm.2009.07.008

Kearney, N., Stack, H. M., Tobin, J. T., Chaurin, V., Fenelon, M. A., Fitzgerald, G. F., et al. (2011). Lactobacillus paracasei NFBC 338 producing recombinant beta-glucanpositively influences the functional properties of yoghurt. Int. Dairy J. 21, 561-567. doi: 10.1016/j.idairyj.2011.03.002

Koo, H., Falsetta, M. L., and Klein, M. I. (2013). The exopolysaccharide matrix: a virulence determinant of cariogenic biofilm. J. Dent. Res. 92, 1065-1073. doi $10.1177 / 0022034513504218$ 
Korakli, M., and Vogel, R. F. (2006). Structure/function relationship of homopolysaccharide producing glycansucrases and therapeutic potential for their synthesized glycans. Appl. Microbiol. Biotechnol. 71, 790-803. doi: 10.1007/s00253-006-0469-4

Kralj, S., van Geel-Schutten, G. H., Dondorff, M. M. G., Kirsanovs, S., van der Maarel, M. J. E. C., and Dijkhuizen, L. (2004). Glucan synthesis in the genus Lactobacillus: isolation and characterization of glucansucrase genes, enzymes and glucan products from six different strains. Microbiology 150, 3681-3690. doi: 10.1099/mic.0.27321-0

Krinos, C. M., Coyne, M. J., Weinacht, K. G., Tzianabos, A. O., Kasper, D. L., and Comstock, L. E. (2001). Extensive surface diversity of a commensal microorganism by multiple DNA inversions. Nature 414, 555-558. doi: $10.1038 / 35107092$

Kumar, A. S., Mody, K., and Jha, B. (2007). Bacterial exopolysaccharides -A perception. J. Basic Microbiol. 47, 103-117. doi: 10.1002/jobm.200610203

Lacaze, G., Wick, M., and Cappelle, S. (2007). Emerging fermentation technologies: development of novel sourdoughs. Food Microbiol. 24, 155-160. doi: 10.1016/j.fm.2006.07.015

Laws, A. P., Chadha, M. J., Chacon-Romero, M., Marshall, V. M., and Maqsood, M. (2008). Determination of the structure and molecular weights of the exopolysaccharide produced by Lactobacillus acidophilus 5e 2 when grown on different carbon feeds Carbohydr. Res. 343, 301-307. doi: 10.1016/j.carres.2007.10.028

Lebeer, S., Verhoeven, T. L., Claes, I. J., De Hertogh, G., Vermeire, S., Buyse, J., et al. (2011). FISH analysis of Lactobacillus biofilms in the gastrointestinal tract of different hosts. Lett. Appl. Microbiol. 52, 220-226. doi: 10.1111/j.1472765X.2010.02994.X

LeBlanc, J. G., Milani, C., de Giori, G. S., Sesma, F., van Sinderen, D., and Ventura, M. (2013). Bacteria as vitamin suppliers to their host: a gut microbiota perspective. Curr. Opin. Biotechnol. 24, 160-168. doi: 10.1016/j.copbio.2012.08.005

Leemhuis, H., Dijkman, W. P., Dobruchowska, J. M., Pijning, T., Grijpstra, P., Kralj, S., et al. (2013a). 4,6- $\alpha$-Glucanotransferase activity occurs more widespread in Lactobacillus strains and constitutes a separate GH70 subfamily. Appl. Microbiol. Biotechnol. 97, 181-193. doi: 10.1007/s00253-0123943-1

Leemhuis, H., Pijning, T., Dobruchowskaa, J. M., van Leeuwena, S. S., Kralj, S., Dijkstrab, B. W., et al. (2013b). Glucansucrases: three-dimensional structures, reactions, mechanism, $\alpha$-glucan analysis and their implications in biotechnology and food applications. J. Biotechnol. 163, 250-272. doi: 10.1016/j.jbiotec.2012.06.037

Leemhuis, H., Pijning, T., Dobruchowska, J. M., Dijkstra, B. W., and Dijkhuizen, L. (2012). Glycosidic bond specificity of glucansucrases: on the role of acceptor substrate binding residues. Biocatal. Biotransformation 30, 366-376. doi: $10.3109 / 10242422.2012 .676301$

Leroy, F., and De Vuyst, L. (2004). Lactic acid bacteria as functional starter cultures for foodfermentation industry. Trends. Food Sci. Technol. 15, 67-78. doi: 10.1016/j.tifs.2003.09.004

Llaubères, R. M., Richard, B., Lonvaud, A., and Dubordieu, D. (1990). Structure of an exocellular h-D-glucan from Pediococcus sp., a wine lactic acid bacteria. Carbohydr. Res. 203, 103-107. doi: 10.1016/0008-6215(90)80049-9

Lynch, K. M., McSweeney, P. L. H., Arendt, E. K., Uniacke-Lowe, T., Galle, S., and Coffey, A. (2014). Isolation and characterisation of exopolysaccharideproducing Weissella and Lactobacillus and their application as adjunct cultures in Cheddar cheese. Int. Dairy J. 34, 125-134. doi: 10.1016/j.idairyj.2013. 07.013

Maeda, H., Zhu, X., Suzuki, S., Suzuki, K., and Kitamura, S. (2004). Structural characterization and biological activities of an exopolysaccharide kefiran produced by Lactobacillus kefiranofaciens WT-2B (T). J. Agric. Food Chem. 52, 5533-5538. doi: 10.1021/jf049617g

Maina, N. H., Virkki, L., Pynnönen, H., Maaheimo, H., and Tenkanen, M. (2011). Structural analysis of enzyme-resistant isomaltooligosaccharides reveals the elongation of $\alpha-(1 \rightarrow 3)$-linked branches in Weissella confusa dextran. Biomacromolecules 12, 409-418. doi: 10.1021/bm1011536

Malang, S. K., Maina, N. H., Schwab, C., Tenkanen, M., and Lacroix, C. (2015). Characterization of exopolysaccharide and ropy capsular polysaccharide formation by Weissella. Food Microbiol. 46, 418-427. doi: 10.1016/j.fm.2014.08.022
Malik, A., Radji, M., Kralj, S., and Dijkhuizen, L. (2009). Screening of lactic acid bacteria from Indonesia reveals glucansucrase and fructansucrase genes in two different Weissella confusa strains from soya. FEMS Microbiol. Lett. 300, 131-138. doi: 10.1111/j.1574-6968.2009.01772.x

Mårtensson, O., Öste, R., and Holst, O. (2002). The effect of yoghurt culture on the survival of probiotic bacteria in oat-based, non-dairy products. Food Res. Int. 35, 775-784. doi: 10.1016/S0963-9969(02)00074-1

Martín, R., Miquel, S., Ulmer, J., Kechaou, N., Langella, P., and BermúdezHumarán, L. G. (2013). Role of commensal and probiotic bacteria in human health: a focus on inflammatory bowel disease. Microb. Cell Fact. 12:71. doi: 10.1186/1475-2859-12-71

McCabe, O., Spinelli, S., Farenc, C., Labbé, M., Tremblay, D., Blangy, S., et al. (2015). The targeted recognition of Lactococcus lactis phages to their polysaccharide receptors. Mol. Microbiol. doi: 10.1111/mmi.12978 [Epub ahead of print].

Medrano, M., Hamet, M. F., Abraham, A. G., and Pérez, P. F. (2009). Kefiran protects Caco-2 cells from cytopathic effects induced by Bacillus cereus infection. Antonie Van Leeuwenhoek 96, 505-513. doi: 10.1007/s10482-0099366-z

Mende, S., Peter, M., Bartels, K., Rohm, H., and Jaros, D. (2013). Addition of purified exopolysaccharide isolates from S. thermophilus to milk and their impact on the rheology of acid gels. Food Hydrocol. 32, 178-118. doi: 10.1016/j.foodhyd.2012.12.011

Meng, G., and Fütterer, K. (2003). Structural framework of fructosyl transfer in Bacillus subtilis levansucrase. Nat. Struct. Biol. 10, 935-941. doi: 10.1038/ nsb974

Meng, G., and Fütterer, K. (2008). Donor substrate recognition in the raffinosebound E342A mutant of fructosyltransferase Bacillus subtilis levansucrase. BMC Struct. Biol. 8:16. doi: 10.1186/1472-6807-8-16

Monchois, V., Willemot, R. M., and Monsan, P. (1999). Glucansucrases: mechanism of action and structure-function relationships. FEMS Microbiol. Rev. 23, 131-151. doi: 10.1111/j.1574-6976.1999.tb00394.x

Monsan, P., Bozonnet, S., Albenne, C., Joucla, G., Willemot, R. M., and RemaudSiméon, M. (2001). Homopolysaccharides from lactic acid bacteria. Int. Dairy J. 11, 675-685. doi: 10.1016/S0958-6946(01)00113-3

Mozzi, F., de Giori, G. S., Oliver, G., and de Valdez, G. F. (1995). Exopolysaccharide production by Lactobacillus casei. II. Influence of the carbon source. Milchwissenschaft 50, 307-309.

Mozzi, F., Vaningelgem, F., Hébert, E. M., van der Meulen, R., Foulquié-Moreno, M. R., Font de Valdez, G., et al. (2006). Diversity of heteropolysaccharide producing lactic acid bacterium strains and their biopolymers. Appl. Environ. Microbiol. 72, 4431-4435. doi: 10.1128/AEM.02780-05

Olano-Martin, E., Mountzouris, K. C., Gibson, G. R., and Rastall, R. A. (2000). In vitro fermentability of dextran, oligodextran and maltodextrin by human gut bacteria. Br. J. Nutr. 83, 247-255.

Olivares-Illana, V., López-Munguía, A., and Olvera, C. (2003). Molecular characterization of inulosucrase from Leuconostoc citreum: a fructosyltransferase within a glucosyltransferase. J. Bacteriol. 185, 3606-3612. doi: 10.1128/JB.185.12.3606-3612.2003

Ortiz, M. E., Bleckwedel, J., Raya, R. R., and Mozzi, F. (2013). Biotechnological and in situ food production of polyols by lactic acid bacteria. Appl. Microbiol. Biotechnol. 97, 4713-4726. doi: 10.1007/s00253-013-4884-z

Ozimek, L. K., Kralj, S., van der Maarel, M., and Dijkhuizen, L. (2006). The levansucrase and inulosucrase enzymes of Lactobacillus reuteri 121 catalyse processive and non-processive transglycosylation reactions. Microbioliology 152, 1187-1196. doi: 10.1099/mic.0.28484-0

Ozturk, S., Aslim, B., and Suludere, Z. (2009). Evaluation of chromium (VI) removal behaviour by two isolates of Synechocystis sp. in terms of exopolysaccharide (EPS) production and monomer composition. Bioresour. Technol. 100, 5588-5593. doi: 10.1016/j.biortech.2009.06.001

Pachekrepapol, U., Horne, D. S., and Lucey, J. A. (2015). Effect of dextran and dextran sulfate on the structural and rheological properties of model acid milk gels. J. Dairy Sci. 98, 2843-2852. doi: 10.3168/jds.2014-8660

Paes Leme, A. F., Koo, H., Bellato, C. M., Bedi, G., and Cury, J. A. (2006). The role of sucrose in cariogenic dental biofilm formation-new insight. J. Dent. Res. 85, 878-887. doi: 10.1177/154405910608501002

Palomba, S., Cavella, S., Torrieri, E., Piccolo, A., Mazzei, P., Blaiotta, G., et al. (2012). Polyphasic screening, homopolysaccharide composition, and 
viscoelastic behavior of wheat Sourdough from a Leuconostoc lactis and Lactobacillus curvatus exopolysaccharide-producing starter culture. Appl. Environ. Microbiol. 78, 2737-2747. doi: 10.1128/AEM.07302-11

Park, J.-H., Ahn, H.-J., Kim, S.-G., and Chung, C.-H. (2013). Dextran-like exopolysaccharide-producing Leuconostoc 053 and Weissella from kimchi and its ingredients. Food Sci. Biotechnol. 22, 1047 doi: 10.1007/s10068-0130182-x

Passerini, D., Vuillemin, M., Ufarté, L., Morel, S., Loux, V., Fontagné-Faucher, C., et al. (2015). Inventory of the GH70 enzymes encoded by Leuconostoc citreum NRRL B-1299 - identification of three novel $\alpha$-transglucosylases. FEBS J. 282, 2115-2130. doi: 10.1111/febs.13261

Patel, S., Majumder, A., and Goyal, A. (2012). Potentials of exopolysaccharides from lactic acid bacteria. Indian J. Microbiol. 52, 3-12. doi: 10.1007/s12088-0110148-8

Patten, D. A., Leivers, S., Chadha, M. J., Maqsood, M., Humphreys, P. N., Laws, A. P., et al. (2014). The structure and immunomodulatory activity on intestinal epithelial cells of the EPSs isolated from Lactobacillus helveticus sp. Rosyjski and Lactobacillus acidophilus sp. 5e2. Carbohydr. Res. 384, 119-127. doi: 10.1016/j.carres.2013.12.008

Pessione, E. (2012). Lactic acid bacteria contribution to gut microbiota complexity: lights and shadows. Front. Cell Infect. Microbiol. 2:86. doi: 10.3389/fcimb. 2012.00086

Picton, L., Bataille, I., and Muller, G. (2000). Analysis of a complex polysaccharide (gum arabic) by multi-angle laser light scattering coupled on-line to size exclusion chromatography and flow field flow fractionation. Carbohyd. Polym. 42, 23-31. doi: 10.1016/S0144-8617(99)00139-3

Piermaria, J. A., de la Canala, M. L., and Abraham, A. G. (2008). Gelling properties of kefiran, a food-grade polysaccharide obtained from kefir grain. Food Hydrocolloid 22, 1520-1527. doi: 10.1016/j.foodhyd.2007. 10.005

Pijning, T., Vujičić-Žagar, A., Kralj, S., Dijkhuizen, L., and Dijkstra, B. W. (2012). Structure of the $\alpha-1,6 / \alpha-1,4$-specific glucansucrase GTFA from Lactobacillus reuteri 121. Acta Crystallogr. Sect. F. Struct. Biol. Cryst. Commun. 68, 1448-1454. doi: 10.1107/S1744309112044168

Polak-Berecka, M., Wa'sco, A., Skrzypek, H., and Kreft, A. (2013). Production of exopolysaccharides by a probiotic strain of Lactobacillus rhamnosus: biosynthesis and purification methods. Acta Alim. 42, 220-228. doi: 10.1556/AAlim.42.2013.2.9

Rao, T. J., and Goyal, A. (2013). A novel high dextran yielding Weissella cibaria JAG8 for cereal food application. Int. J. Food Sci. Nutr. 64, 346-354. doi: 10.3109/09637486.2012.734289

Robert, H., Gabriel, V., and Fontagné-Faucher, C. (2009). Biodiversity of lactic acid bacteria in French wheat sourdough as determined by molecular characterization using species-specific PCR. Int. J. Food Microbiol. 135, 53-59. doi: 10.1016/j.ijfoodmicro.2009.07.006

Rodriguez, C., Van der Meulen, R., Vaningelgem, F., Font de Valdez, G., Raya, R. R., De Vuyst, L., et al. (2008). Sensitivity of capsular-producing Streptococcus thermophilus strains to bacteriophage adsorption. Lett. Appl. Microbiol. 46, 462-468. doi: 10.1111/j.1472-765X.2008.02341.x

Rolland-Sabate, A., Colonna, P., Mendez-Montealvo, M. G., and Planchot, V. (2007). Branching features of amylopectins and glycogen determined by asymmetrical flow field flow fractionation coupled with multiangle laser light scattering. Biomacromolecules 8, 2520-2532. doi: 10.1021/bm07 $0024 z$

Ruas-Madiedo, P., Abraham, A., Mozzi, F., and de los Reyes-Gavilán, C. (2008). "Functionality of exopolysaccharides produced by lactic acid bacteria," in Molecular Aspects of Lactic Acid Bacteria for Traditional and New Applications, eds B. Mayo, P. López, and G. Pérez-Martínez (Kerala: Research Signpost), $138-166$.

Ruas-Madiedo, P., and de los Reyes-Gavilán, C. G. (2005). Methods for the screening, isolation, and characterization of exopolysaccharides produced by lactic acid bacteria. J. Dairy Sci. 88, 843-856. doi: 10.3168/jds.S00220302(05)72750-8

Ruas-Madiedo, P., Salazar, N., and de los Reyes-Gavilán, G. C. (2009a). "Biosynthesis andchemical composition of exopolysaccharides produced by lactic acid bacteria," in Bacterial Polysaccharides, Current Innovations and Future Trends, ed. M. Ullrich (Norfolk: Caister Academic Press), 279-310.
Ruas-Madiedo, P., Salazar, N., and de los Reyes-Gavilán, G. C. (2009b). "Exopolysaccharidesproduced by lactic acid bacteria in food and probiotic applications," in Microbial Glycobiology, Structures, Relevance and Applications, eds A. P. Moran, O. Holst, P. J. Brennan, and M. von Itzstein (London: Academic Press, Elsevier), 887-902.

Ruas-Madiedo, P., Sánchez, B., Hidalgo-Cantabrana, C., Margolles, A., and Laws, A. (2012). "Exopolysaccharides from lactic acid bacteria and bifidobacteria," in Handbook of Animal Based Fermented Food and Beverage Technology, 2nd Edn, ed. Y. H. Hui and E. O. Evranuz (Boca Raton, FL: CRC Press, Taylor \& Francis group), 125-151.

Rühmkorf, C., Bork, C., Mischnick, P., Ruebsam, H., Becker, T., and Vogel, R. F. (2013). Identification of Lactobacillus curvatus TMW 1.624 dextransucrase and comparative characterization with Lactobacillus reuteri TMW 1.106 and Lactobacillus animalis TMW 1.971 dextransucrases. Food Microbiol. 34, 52-61. doi: 10.1016/j.fm.2012.11.002

Rühmkorf, C., Ruebsam, H., Becker, T., Bork, C., Voiges, K., Mischnick, P., et al. (2012). Effect of structurally different microbial homoexopolysaccharides on the quality of gluten-free bread. Eur. Food Res. Technol. 235, 139-146. doi: 10.1007/s00217-012-1746-3

Russell, R. R. B. (1994). The application of molecular genetics to the microbiology of dental caries. Caries Res. 28, 69-82. doi: 10.1159/000261625

Russo, P., López, P., Capozzi, V., de Palencia, P. F., Dueñas, M. T., Spano, G., et al. (2012). Beta-glucans improve growth, viability and colonization of probiotic microorganisms. Int. J. Mol. Sci. 13, 6026-6039. doi: 10.3390/ijms130 56026

Ryan, P. M., Ross, R. P., Fitzgerald, G. F., Caplice, N. M., and Stanton, C. (2015). Sugar-coated: exopolysaccharide producing lactic acid bacteria for food and human health applications. Food Funct. 6, 679-693. doi: 10.1039/ c4fo00529e

Salazar, N., Gueimonde, M., de los Reyes-Gavilán, C. G., and Ruas-Madiedo, P. (2015). Exopolysaccharides produced by lactic acid bacteria and bifidobacteria as fermentable substrates by the intestinal microbiota. Crit. Rev. Food Sci. Nutr. doi: 10.1080/10408398.2013.770728 [Epub ahead of print].

Salazar, N., Prieto, A., Leal, J. A., Mayo, B., Bada-Gancedo, J. C., de los ReyesGavilán, C. G., (2009). Production of exopolysaccharides by Lactobacillus and Bifidobacterium strains of human origin, and metabolic activity of the producing bacteria in milk. J. Dairy Sci. 92, 4158-4168. doi: 10.3168/jds.20092126

Sánchez, J. I., Martínez, B., Guillén, R., Jiménez-Díaz, R., and Rodríguez, A. (2006). Culture conditions determine the balance between two different exopolysaccharides produced by Lactobacillus pentosus LPS26. Appl. Environ. Microbiol. 72, 7495-7502. doi: 10.1128/AEM.01078-06

Sanz, M. L., and Martinez-Castro, I. (2007). Recent developments in sample preparation for chromatographic analysis of carbohydrates. J. Chromatog. A 1153, 74-89. doi: 10.1016/j.chroma.2007.01.028

Schwab, C., Mastrangelo, M., Corsetti, A., and Gänzle, M. (2008). Formation of oligosaccharides and polysaccharides by Lactobacillus reuteri LTH5448 and Weissella cibaria 10M in sorghum sourdoughs. Cereal Chem. J. 85, 679-684. doi: 10.1094/CCHEM-85-5-0679

Schwab, C., Walter, J., Tannock, G. W., Vogel, R. F., and Gänzle, M. G. (2007). Sucrose utilization and impact of sucrose on glycosyltransferase expression in Lactobacillus reuteri. Syst. Appl. Microbiol. 30, 433-443. doi: 10.1016/j.syapm.2007.03.007

Shao, L., Wub, Z., Tiana, F., Zhanga, H., Liub, Z., Chena, W., et al. (2015). Molecular characteristics of an exopolysaccharide from Lactobacillus rhamnosus KF5 in solution. Int. J. Biol. Macromol. 72, 1429-1434. doi: 10.1016/j.ijbiomac.2014.10.015

Shiroza, T., and Kuramitsu, H. K. (1988). Sequence analysis of the Streptococcus mutans fructosyltransferase gene and flanking regions. J. Bacteriol. 170, 810816.

Shukla, R., and Goyal, A. (2011). 16S rRNA-based identification of a glucan-hyperproducing Weissella confusa. Enzyme Res. 2011:250842. doi: $10.4061 / 2011 / 250842$

Shukla, R., and Goyal, A. (2013). Novel dextran from Pediococcus pentosaceus CRAG3 isolated from fermented cucumber with anti-cancer properties. Int. J. Biol. Macromol. 62, 352-357. doi: 10.1016/j.ijbiomac.2013.09.043

Shukla, R., and Goyal, A. (2014). Purified dextransucrase from Pediococcus pentosaceus CRAG3 as food additive. Ind. J. Exper. Biol. 52, 1036-1044. 
Shukla, R., Iliev, I., and Goyal, A. (2010). Purified dextransucrase from Leuconostoc mesenteroides NRRL B-1149. Biotechnol. Biotechnol. Equip. 24, 576-580. doi: $10.1080 / 13102818.2010 .10817900$

Shukla, R., Shukla, S., Bivolarski, V., Iliev, I., Ivanova, I., and Goyal1, A. (2011), Structural characterization of insoluble dextran produced by Leuconostoc mesenteroides NRRL B-1149 in the presence of maltose. Food Technol. Biotechnol. 49, 291-296.

Song, Y.-R., Jeong, D.-Y., Cha, Y.-S., and Baik, S.-H. (2013). Exopolysaccharide produced by Pediococcus acidilactici M76 isolated from the Korean traditional rice wine, Makgeolli. J. Microbiol. Biotechnol. 23, 681-688. doi: 10.4014/jmb.1301.01032

Stack, H. M., Kearney, N., Stanton, C., Gerald, F., Fitzgerald, G. F., and Ross, R. P. (2010). Association of $\beta$-glucan endogenous production with increased stress tolerance of intestinal lactobacilli. Appl. Environ. Microbiol. 76, 500-507. doi: 10.1128/AEM.01524-09

Teixeira, J. S., McNeill, V., Gänzle, M. G. (2012). Levansucrase and sucrose phoshorylase contribute to raffinose, stachyose, and verbascose metabolism by lactobacilli. Food Microbiol. 31, 278-284. doi: 10.1016/j.fm.2012.03.003

Tieking, M., Ehrmann, M. A., Vogel, R. F., and Gänzle, M. G. (2005a). Molecular and functional characterization of a levansucrase from the sourdough isolate Lactobacillus sanfranciscensis TMW 1.392. Appl. Microbiol. Biotechnol. 66, 655-663. doi: 10.1007/s00253-004-1773-5

Tieking, M., Kaditzky, S., Valcheva, R., Korakli, M., Vogel, R. F., and Gänzle, M. G. (2005b). Extracellular homopolysaccharides and oligosaccharides from intestinal lactobacilli. J. Appl. Microbiol. 99, 692-702. doi: 10.1111/j.13652672.2005.02638.x

Tieking, M., and Gänzle, M. G. (2005). Exopolysaccharides from cereal-associated lactobacilli. Trends Food Sci. Technol. 16, 79-84. doi: 10.1016/j.tifs.2004.02.015

Tieking, M., Korakli, M., Ehrmann, M. A., Gänzle, M. G., and Vogel, R. F. (2003). In situ production of exopolysaccharides during sourdough fermentation by cereal and intestinal isolates of lactic acid bacteria. Appl. Environ. Microbiol. 69, 945-952. doi: 10.1128/AEM.69.2.945-952.2003

Tingirikari, J. M., Kothari, D., Shukla, R., and Goyal, A. (2014). Structural and biocompatibility properties of dextran from Weissella cibaria JAG8 as food additive. Int. J. Food Sci. Nutr. 65, 686-691. doi: 10.3109/09637486.2014.917147

Torino, M. I., Hébert, E. M., Mozzi, F., and Font de Valdez, G. (2005). Growth and exopolysaccharide production by Lactobacillus helveticus ATCC 15807 in an adenine-supplemented chemically defined medium. J. Appl. Microbiol. 99, 1123-1129. doi: 10.1111/j.1365-2672.2005.02701.x

Trancoso-Reyes, N., Gutiérrez-Méndez, N., Sepulveda, D. R., and HernándezOchoa, L. R. (2014). Assessing the yield, microstructure, and texture properties of miniature Chihuahua-type cheese manufactured with a phospholipase A1 and exopolysaccharide-producing bacteria. J. Dairy Sci. 97, 598-608. doi: $10.3168 /$ jds.2013-6624

Tuinier, R., van Casteren, W. H., Looijesteijn, P. J., Schols, H. A., Voragen, A. G., and Zoon, P. (2001). Effects of structural modifications on some physical characteristics of exopolysaccharides from Lactococcus lactis. Biopolymers 59, 160-166. doi: 10.1002/1097-0282(200109)59:3<160::AID-BIP1015>3.0.CO;2-V

Uzochukwu, S., Balogh, E., Loefer, R. T., and Ngoddy, P. O. (2001). Structural analysis by $13 \mathrm{C}$-nuclear resonance spectroscopy of glucans elaborated by gumproducing bacteria isolated from palm wine. Food Chem. 73, 225-233. doi: 10.1016/S0308-8146(00)00291-0

Van der Meulen, R., Grosu-Tudor, S., Mozzi, F., Vaningelgem, F., Zamfir, M., Font de Valdez, G., et al. (2007). Screening of lactic acid bacteria ioslates from dairy and cereal products for exopolysaccharide production and genes envolved. Int. J. Food Microbiol. 118, 250-258. doi: 10.1016/j.ijfoodmicro.2007.07.014

van Geel-Schutten, G. H., Faber, E. J., Smit, E., Bonting, K., Smith, M. R., Ten Brink, B., et al. (1999). Biochemical and structural characterization of the glucan and fructan exopolysaccharides synthesized by the Lactobacillus reuteri wild-type strain and by mutant strains. Appl. Environ. Microbiol. 65, 3008-3014.

van Geel-Schutten, G. H., Flesch, F., Ten Brink, B., Smith, M. R., and Dijkhuizen, L. (1998). Screening and characterization of Lactobacillus strains producing large amounts of exopolysaccharides. Appl. Microbiol. Biotechnol. 50, 697-703. doi: $10.1007 / \mathrm{s} 002530051353$

van Hijum, S. A., Kralj, S., Ozimek, L. K., Dijkhuizen, L., and van GeelSchutten, I. G. H. (2006). Structure-function relationships of glucansucrase and fructansucraseenzymesfrom lactic acid bacteria. Microbiol. Mol. Biol. Rev. 70, 157-176. doi: 10.1128/MMBR.70.1.157-176.2006 van Hijum, S. A., Szalowska, E., Van Der Maarel, M. J., and Dijkhuizen, L. (2004). Biochemical and molecular characterization of a levansucrase from Lactobacillus reuteri. Microbiology 150, 621-630. doi: 10.1099/mic.0.26671-0

van Hijum, S. A., Van Der Maarel, M. J., and Dijkhuizen, L. (2003). Kinetic properties of an inulosucrase from Lactobacillus reuteri 121. FEBS Lett. 534, 207-210. doi: 10.1016/S0014-5793(02)03841-3

van Hijum, S. A., van Schutten, G. H., Rahaoui, H., van der Maarel, M. J., and Dijkhuizen, L. (2002). Characterization of a novel fructosyltransferase from Lactobacillus reuteri that synthesized high-molecular-weight inulin and inulin oligosaccharides. Appl. Environ. Microbiol. 68, 4390-4398. doi: 10.1128/AEM.68.9.4390-4398.2002

van Kranenburg, R., Marugg, J. D., van Swam, I. I., Willem, N. J., and de Vos, W. M. (1997). Molecular characterization of the plasmid-encoded eps gene cluster essential for exopolysaccharide biosynthesis in Lactococcus lactis. Mol. Microbiol. 24, 387-397. doi: 10.1046/j.1365-2958.1997.3521720.x

van Kranenburg, R., Voss, H. R., Van Swam, I. I., Willem, N. J., and De Vos, W. M. (1999). Functional analysis of glycosyltransferases genes from Lactococcus lactis and other gram-positive cocci: complementation, expression, and diversity. J. Bacteriol. 181, 6347-6353.

van Leeuwen, S. S., Kralj, S., Eeuwema, W., Gerwig, G. J., Dijkhuizen, L., and Kamerling, J. P. (2009). Structural characterization of bioengineered $\alpha$-Dglucans produced by mutant glucansucrase GTF180 enzymes of Lactobacillus reuteri strain 180. Biomacromolecules 10, 580-588. doi: 10.1021/bm801240r

Vaningelgem, F., Zamfir, M., Mozzi, F., Adriany, T., Vancanneyt, M., Swings, J., et al. (2004). Biodiversity of exopolysaccharides produced by Streptococcus thermophilus strains is reflected in their production and their molecular and functional characteristics. Appl. Environ. Microbiol. 70, 900-912. doi: 10.1128/AEM.70.2.900-912.2004

Vasileva, T., Kirilov, A., Bivolarski, V., Bounaix, M. S., Herve Robert, V. G., Fontagne-Faucher, C., et al. (2009). Characterization of glycansucrase activities from Leuconostoc mesenteroides LM17 and URE 13 Strains. Biotechnol. Biotechnol. Equip. 23, 698-701. doi: 10.1080/13102818.2009.10818520

Velasco, S. E., Yebra, M. J., Monedero, V., Ibarburu, I., Dueñas, M. T., and Irastorza, A. (2007). Influence of the carbohydrate source betaglucan production andenzyme activities involved in sugar metabolism in Pediococcusparvulus 2.6. Int. J. Food Microbiol. 115, 325-334. doi: 10.1016/j.ijfoodmicro.2006.12.023

Vujičić-Žagar, A., Pijning, T., Kralj, S., López, C. A., Eeuwema, W., Dijkhuizen, L., et al. (2010). Crystal structure of a $117 \mathrm{kDa}$ glucansucrase fragment provides insight into evolution and product specificity of GH70 enzymes. Proc. Nat. Acad. Sci. U.S.A. 107, 21406-21411. doi: 10.1073/pnas.1007531107

Waldherr, F. W., Doll, V. M., Meißner, D., and Vogel, R. F. (2010). Identification and characterization of a glucan-producing enzyme from Lactobacillus hilgardii TMW 1.828 involved in granule formation of water kefir. Food Microbiol. 27, 672-678. doi: 10.1016/j.fm.2010.03.013

Wang, K., Li, W., Rui, X., Chen, X., Jiang, M., and Dong, M. (2014). Characterization of a novel exopolysaccharide with antitumor activityfrom Lactobacillus plantarum 70810. Int. J. Biol. Macromol. 63, 133-139. doi: 10.1016/j.ijbiomac.2013.10.036

Wang, W., Zhang, L., and Li, Y. (2012). Production of volatile compounds in reconstituted milk reduced-fat cheese and the physicochemical properties as affected by exopolysaccharide-producing strain. Molecules 17, 14393-14408. doi: $10.3390 /$ molecules 171214393

Wang, Y., Ahmed, Z., Feng, W., Li, C., and Song, S. (2008). Physicochemical properties of exopolysaccharide produced by Lactobacillus kefiranofaciens ZW3 isolated from Tibet kefir. Int. J. Biol. Macromol. 43, 283-288. doi: 10.1016/j.ijbiomac.2008.06.011

Welman, A. D., and Maddox, I. S. (2003). Exopolysaccharides from lactic acid bacteria: perspectives and challenges. Trends Biotechnol. 21, 269-274. doi: 10.1016/S0167-7799(03)00107-0

Werning, M. L., Corrales, M. A., Prieto, A., Fernández de Palencia, P., Navas, J., and López, P. (2008). Heterologous expression of a position 2-substituted (1 $\rightarrow 3$ )beta-d-glucan in Lactococcus lactis. Appl. Environ. Microbiol. 74, 5259-5262. doi: 10.1128/AEM.00463-08

Werning, M. L., Ibarburu, I., Dueñas, M. T., Irastorza, A., Navas, J., and López, P. (2006). Pediococcus parvulus gtf gene encoding the GTF glycosyltransferase and its application for specific PCR detection of b-D-glucan-producing bacteria in foods and beverages. J. Food Prot. 69, 161-169. 
Wolter, A., Hager, A. S., Zannini, E., Galle, S., Gänzle, M. G., Waters, D. M., et al. (2014a). Evaluation of exopolysaccharide producing Weissella cibaria MG1 strain for the production of sourdough from various flours. Food Microbiol. 37, 44-50. doi: 10.1016/j.fm.2013.06.009

Wolter, A., Hager, A.-S., Zannini, E., Czerny, M., and Arendt, E. K. (2014b). Influence of dextran-producing Weissella cibaria on baking properties and sensory profile of gluten-free and wheat breads. Int. J. Food Microbiol. 172, 83-91. doi: 10.1016/j.ijfoodmicro.2013.11.015

Wood, B. J. B., and Holzapfel, W. H. (1995). The Genera of Lactic Acid Bacteria, Vol. 2. Glasgow: Blackie Academic and Professional. doi: 10.1007/978-1-46155817-0

Wood, P. J. (1997). Oats as a functional food for health-the role of $\beta$-glucan. Can. Chem. News 53, 17-19.

Zannini, E., Mauch, A., Galle, S., Gänzle, M., Coffey, A., Arend, E. K., et al. (2013). Barley malt wort fermentation by exopolysaccharide forming Weissella cibaria MG1 for the production of a novel beverage. J. Appl. Microbiol. 115, 1379-1387. doi: $10.1111 /$ jam. 12329

Zekovic, D. B., Kwiatkowski, S., Vrvic, M. M., Jakovljevic, D., and Moran, C. A. (2005). Natural and modified $(1 \rightarrow 3)-\beta$-d-glucans in health promotion and disease alleviation. Crit. Rev. Biotechnol. 25, 205-230. doi: $10.1080 / 07388550500376166$
Zisu, B. (2005). Impact of Pre-Acidification, Fat Replacers and Exopolysaccharide Producingstarter Cultures on Functionality of Low Fat Mozzarella Cheese. Ph.D. thesis, Victoria University, Victoria.

Zisu, B., and Shah, N. P. (2003). Effects of pH, temperature, supplementation with wheyprotein concentrate, and adjunct cultures on the production ofexopolysaccharides by Streptococcus thermophilus 1275. J. Dairy Sci. 86, 3405-3415. doi: 10.3168/jds.S0022-0302(03)73944-7

Conflict of Interest Statement: The Associate Editor Julia Ines Fariña declares that, despite being affiliated with the same institution as authors María Inés Torino, Graciela Font de Valdez and Fernanda Mozzi, the review process was handled objectively. The authors declare that the research was conducted in the absence of any commercial or financial relationships that could be construed as a potential conflict of interest.

Copyright $\odot 2015$ Torino, Font de Valdez and Mozzi. This is an open-access article distributed under the terms of the Creative Commons Attribution License (CC BY). The use, distribution or reproduction in other forums is permitted, provided the original author(s) or licensor are credited and that the original publication in this journal is cited, in accordance with accepted academic practice. No use, distribution or reproduction is permitted which does not comply with these terms. 